\title{
The International Tax Environment and Simplification of South African Tax Legislation: A Double-Edged Sword
}

Jinyan Li

Osgoode Hall Law School of York University, jli@osgoode.yorku.ca

Teresa Pidduck

University of Pretoria

Source Publication:

Submitted for publication in C. Evans, R. Franzsen, E. Stack (eds.). Tax Simplification: An African Perspective (forthcoming 2019)

Follow this and additional works at: https://digitalcommons.osgoode.yorku.ca/scholarly_works

Part of the International Law Commons, and the Tax Law Commons

\section{Repository Citation}

$\mathrm{Li}$, Jinyan and Pidduck, Teresa, "The International Tax Environment and Simplification of South African Tax Legislation: A Double-Edged Sword" (2019). Articles \& Book Chapters. 2705.

https://digitalcommons.osgoode.yorku.ca/scholarly_works/2705

This Book Chapter is brought to you for free and open access by the Faculty Scholarship at Osgoode Digital Commons. It has been accepted for inclusion in Articles \& Book Chapters by an authorized administrator of Osgoode Digital Commons. 


\title{
The international tax environment and simplification of South African tax legislation: a double-edged sword
}

\author{
Jinyan Li* \& Teresa Pidduck** \\ Submitted for publication in C. Evans, R. Franzsen, E. Stack (eds.). Tax Simplification: \\ An African Perspective (forthcoming 2019) \\ * Professor, Osgoode Hall Law School, York University, Canada; \\ ** Senior Lecturer, Faculty of Economic and Management Sciences \\ Department of Taxation, University of Pretoria, South Africa \\ We thank Cecil Morden for his insightful comments on an earlier version \\ presented at an international symposium on Tax Simplification: An African \\ Perspective at Johannesburg, South Africa on October 10-11, 2018. We also \\ thank Jin Bao, a JD student at Osgoode Hall Law School, for his excellent \\ research assistance, Rika Opper for her editorial assistance, and Osgoode Hall \\ Law School for the funding support.
}




\begin{abstract}
In this paper, we examine the relationship between the international tax environment and legislative complexity in South Africa's international tax system. We suggest that the international tax environment is a doubleedged sword. It causes complexity in South Africa's tax legislation as it largely responds to the needs of OECD countries and produces tax rules to deal with 'sophisticated' tax problems and taxpayers (such as multinational enterprises). When such rules are transplanted into South Africa, they are typically more complex than local rules dealing with local taxpayers. On the other hand, the international tax environment offers ideas for 'scientific' drafting of South Africa's tax legislation, which may lead to simplification and enhanced effectiveness in tax compliance and administration. We contribute to the literature on tax simplification by focusing on legislative complexity and distinguishing between intrinsic complexity and drafting-led complexity. We recommend ways of legislative simplification by drawing on the international tax environment.
\end{abstract}




\section{Contents}

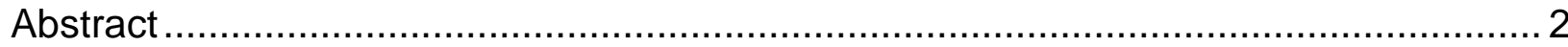

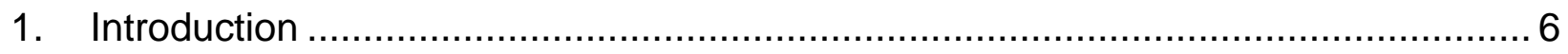

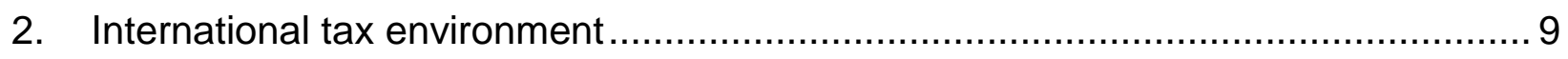

2.1 The notion of an international tax environment and its relevance .................... 9

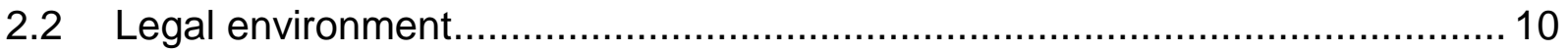

2.2.1 Tax sovereignty and interaction of national tax laws ............................ 10

2.2.2 International tax rules are more complex........................................... 12

2.2.3 The rise of anti-avoidance rules....................................................... 13

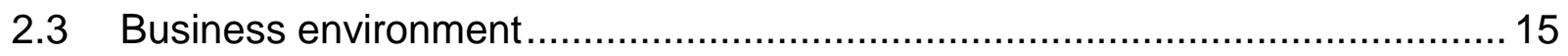

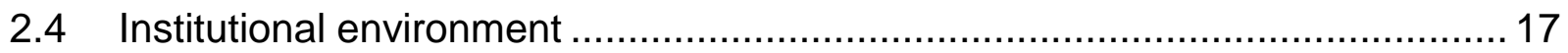

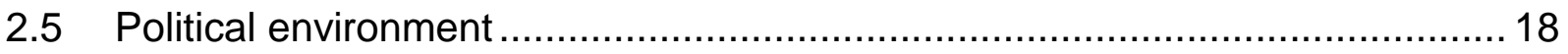

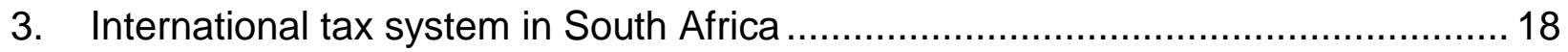

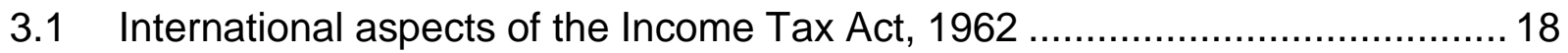

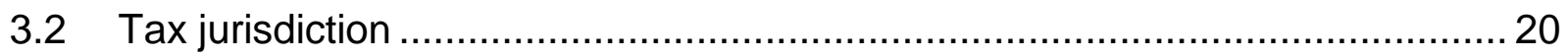

3.3 Outbound rules - resident companies earning foreign income ...................... 21

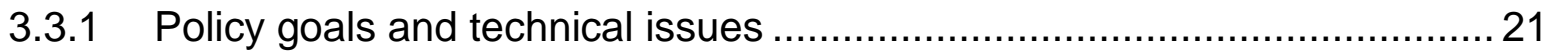

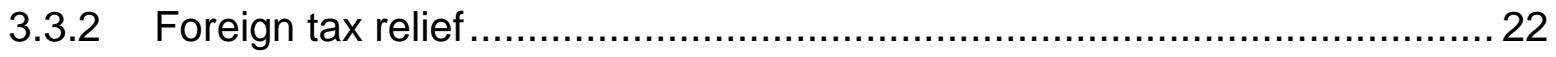

3.3.3 Controlled foreign corporations (CFCs) …........................................ 23

3.4 Inbound rules: non-resident companies earning domestic income $\ldots \ldots \ldots \ldots \ldots \ldots \ldots . .25$

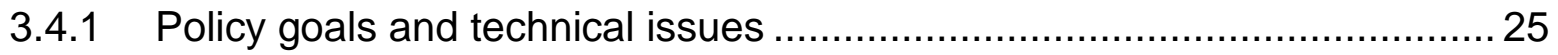

3.4.2 Business income and normal tax liability .......................................... 26

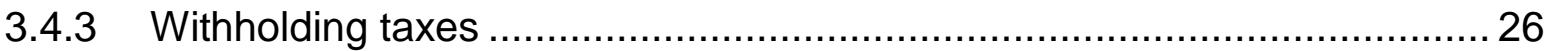

3.5 Inbound and outbound rules: headquarter company regime ….................... 28 


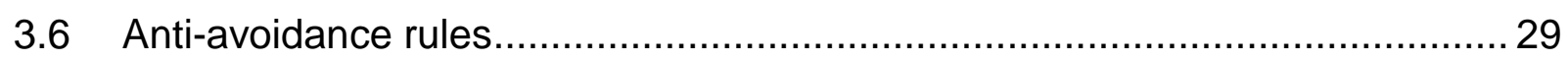

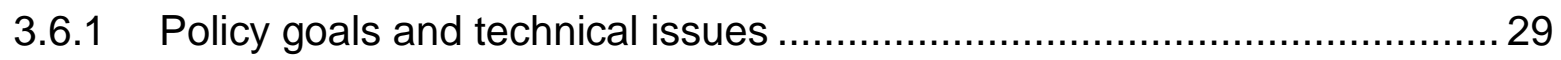

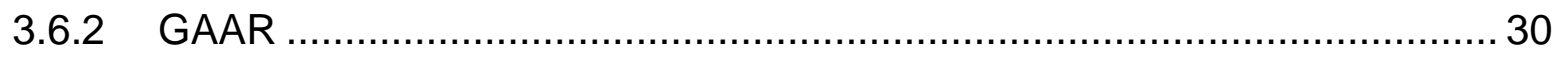

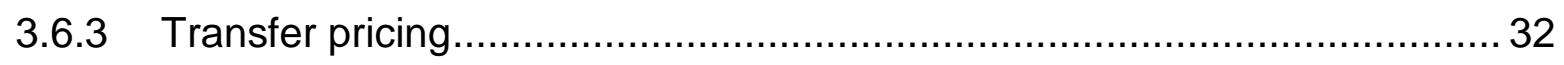

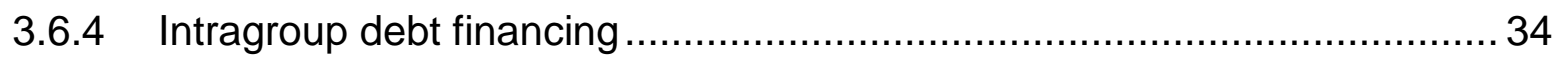

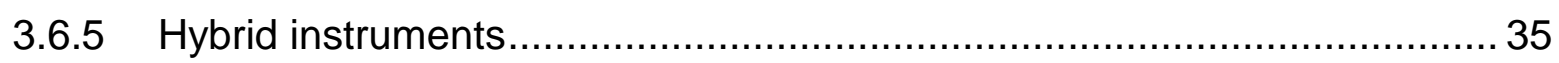

3.6.6 Roundtripping of intellectual property …............................................ 36

4. Legislative complexity of the international tax system ......................................... 37

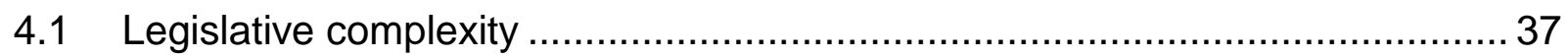

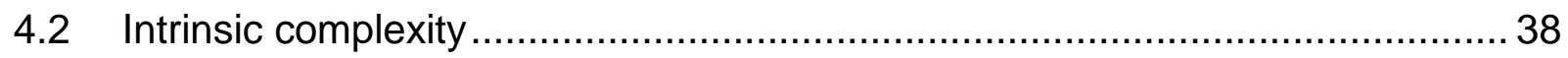

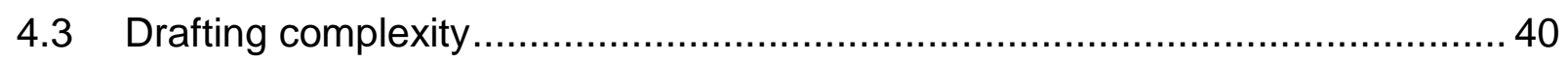

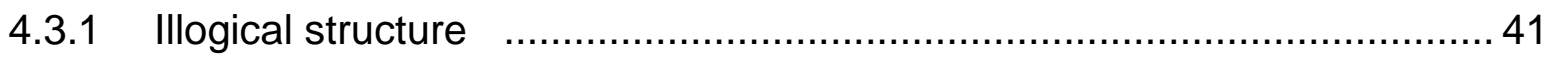

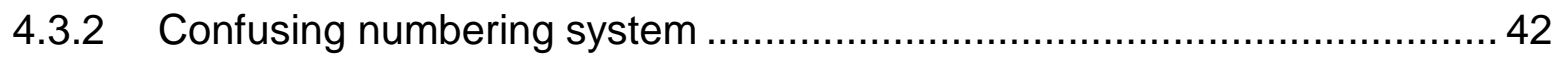

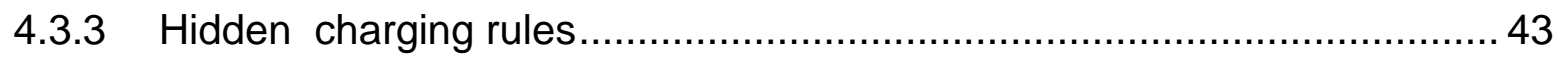

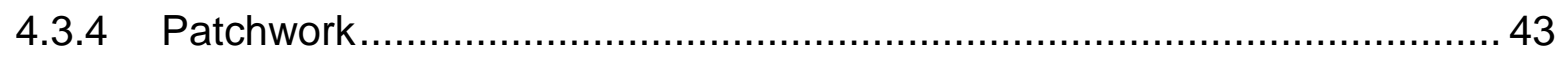

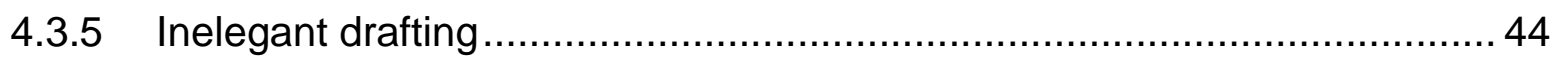

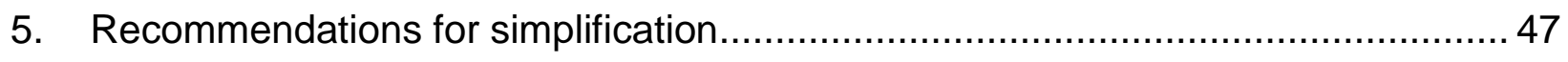

5.1 Living with reasonable intrinsic complexity ................................................. 47

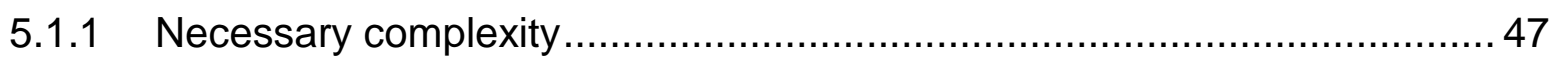

5.1.2 Tailored for South Africa ................................................................. 48

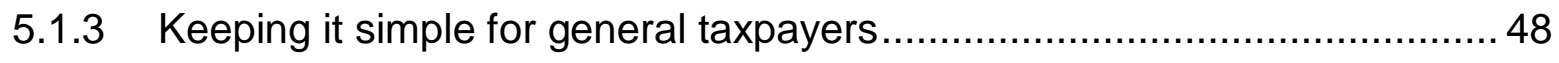

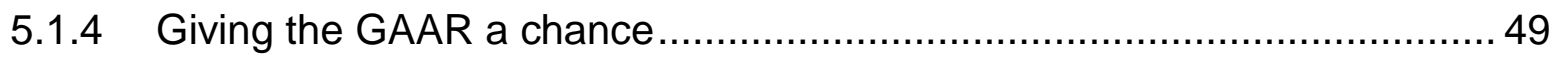

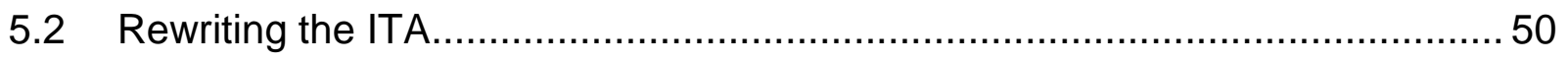

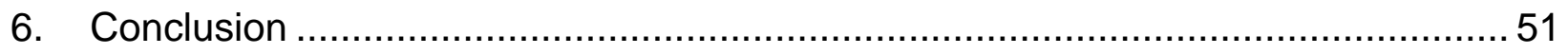




\section{Introduction}

In this paper, we consider the influence of the international tax environment on tax simplification in South Africa. More specifically, we examine the international aspects of the Income Tax Act No. 58 of 1962, as amended (the ITA), concerning corporations, explore the extent to which legislative complexity is caused by the international tax environment or drafting choices and suggest ways of simplifying the legislation by drawing on the international tax environment. We view the international tax environment as a double-edged sword in both causing the complexity and helping reduce the complexity.

The issue of tax complexity and calls for tax simplification feature prominently in literature on South Africa taxation ${ }^{1}$ and commissioned reports, such as those compiled by the Katz Commission and the Davis Tax Committee. ${ }^{2}$ As a multifaceted and relative concept, ${ }^{3}$ tax complexity (or the other side of the coin - tax simplification) can be understood to include legal (statutory, coding or substantive) complexity ${ }^{4}$ and effective

$1 \quad$ T Steyn \& M Stiglingh 'The complexity of tax simplification: Experiences from South Africa' (2016) in J Sawyer \& T Budak (eds) The complexity of tax simplification: Experiences from South Africa 157; $\mathrm{K}$ Mandy 'Rewriting SA tax law'. FANews. [Online http://www.fanews.co.za/article/tax/16/tax/1016/therewriting-of-sa-s-income-act/13112; and papers in this current volume (visited on 18 September 2018).

2 'Margo Commission of inquiry into the tax structure of the Republic of South Africa' (1987); 'The third interim report of the Katz Commission of Inquiry Into Taxation (1997)'; 'Davis Tax Committee reports' (2015-2018) http://www.taxcom.org.za (accessed 20 October 2018), in particular the 'Macro analysis final report'; 'Base erosion and profit shifting' (BEPS) final report; 'Corporate income tax report'.

3 B Tran-Nam 'Tax reform and tax simplification: Conceptual and measurement issues and Australian experiences' in S James, A Sawyer \& T Budak (eds.) The Complexity of Tax Simplification: Experiences from around the world (2016) (Hampshire: Palgrave Macmillan) 14l; and B Tran-Nam \& C Evans 'Towards the Development of a Tax System Complexity Index' (2014) 35(3) Fiscal Studies 345. For further, see G Cooper, 'Themes and Issues in Tax Simplification' (1993) 10 Australian Tax Forum 417; C Evans and J Kerr 'Tax reform and 'rough justice': is it time for simplicity to shine' (2012) 27 Australian Tax Forum 388; D Paul 'The Sources of Tax Complexity: How Much Simplicity Can Fundamental Tax Reform Achieve' (1997-1998) 76 North Carolina Law Review 151; J Partlow 'The Necessity of Complexity in the Tax System' (2013)13 Wyoming Law Review 304; S A Donaldson 'The Easy Case against Tax Simplification' (2002-2003) 22 Virginia Tax Review 645; and M Walpole 'Tax complexity: A necessary evil?' in C Evans, R Krever \& P Mellor (Eds.), Tax Simplification (pp. 181 - 192) ( Alphen aan den Rijn Netherlands: Kluwer Law International 2015).

$4 \quad$ The term 'legislative complexity' can be used in a general sense to refer to what Surrey called the "complex technical structure" of tax statute, that is, "complex substantive tax rules with complex interrelationships, characterized by complex variations in the tax treatment of transactions often not differing greatly in substance or form, all of which are expressed in a complex statutory terminology and 
(administrative and compliance or operational) complexity. ${ }^{5}$ Legal complexity relates to the difficulty in reading and understanding the tax law owing to the structure and substantive provisions of the legislation, while the effective complexity relates to the difficulty in administering and complying with the law. Both types of tax complexity have been noted in the South African context. The tax legislation has been described as "far too onerous and complicated and the associated tax compliance and reporting requirements are becoming too burdensome and expensive to comply with". ${ }^{6}$ The level of complexity is such that only dedicated tax professionals are able to understand it. ${ }^{7}$ In addition to legislative complexity, tax complexity may be caused by the so-called efficiency (economic growth) versus equity (social justice) trade-off and tax simplification has thus been identified as being critical to achieving broader policy objectives.

We aim to contribute to the debates on tax simplification in South Africa by focusing on legislative complexity and its relationship to the international tax environment. Evidence of legislative complexity seems clear and undebatable. More specifically, we investigate the causes and solutions of legislative complexity as we assume that the evidence of legislative complexity is clear and beyond debate and legislative simplification is a pre-condition for effective simplicity. For example, the ITA lacks a clear structure and has not modernized its 'colonial' architecture that goes back to the Income Tax Act No. 28 of 1914, which was modelled on the New South Wales Act of $1895 .{ }^{8}$ The legislation

arrangement." See S S Surrey in "Complexity and the Internal Revenue Code: The problem of the management of tax detail' (1969) Law and Contemporary Problems Vol. 34, No. 4, Tax Simplification and Reform) 673 at 673.

5 B. Tran-Nam 'Tax Reform and Tax Simplification: Some Conceptual Issues and a Preliminary Assessment' (1999) 21 Sydney Law Review 500; B Tran-Nam, C Evans, R Krever \& P Lignier 'Managing Tax Complexity: The State of Play after Henry (2016) 35 Economic Papers 349; The Office of Tax Simplification (OTS), United Kingdom, has identified legislative complexity, effectiveness and resource efficiency as the key areas of importance in usability framework: see Office of Tax Simplification, The Office of Tax Simplification Complexity Index (2012); http://taxsimplificationblog.files.wordpress.com/2012/12/otscomplexity-index-methodology-paper1.pdf (accessed 20 October, 2018).

6 Davis Tax Committee, Closing Report (March 2018). Available at: http://www.taxcom.org.za/library.html (accessed 20 October 2018).

7 R Oberholzer 'Perceptions of Taxation: A comparative study of different population groups in South Africa' unpublished PhD thesis, University of Pretoria, 2007, 33 (on file with the author).

$8 \quad$ The 1914 legislation was subject to numerous amendments and culminated in the enactment of the 1962 legislation. Since its enactment in 1962, the ITA has similarly been amended over 100 times, but 
appears to be body of patchwork. Even though the South Africa Revenue Services (SARS) can simplify the complex tax rules through administrative guidance, forms and procedures, such effective simplification has its limits. Under the rule of law, tax liability can be created only by statutory law and SARS's mandate is limited to applying the ITA provisions.

We examine the legal complexity of the ITA rules by distinguishing between 'intrinsic' complexity and 'drafting-based complexity', which are the subsets of legal complexity. Intrinsic complexity refers to the complexity owing to the intrinsic nature of international taxation. Drafting-based complexity refers to complexity caused by drafting choices and techniques. We suggest that the international tax environment is one of the causes and solutions of legislative complexity in South Africa. We seek to advance the literature on tax simplification in respect of (un)necessary complexity or (un)avoidable complexity.

Our central claim is that South Africa's tax simplification efforts should recognize the intrinsic complexity of international tax rules and remove the unnecessary complexity caused by drafting choices, and do so by considering the international tax environment. We draw on the existing literature on tax complexity (or simplification) and adopt a limited comparative approach to analysing drafting complexity.

The structure of this paper is as follows: Part 2 and Part 3 provide the necessary background for our diagnosis and solution of the legislative complexity problem. Part 2 describes the international tax environment in terms of the legal, business, institutional and political elements. Part 3 presents the corporate international tax system in South Africa at a fairly technical level in terms of the rules governing tax jurisdiction, the taxation of resident taxpayers earning income from foreign sources (outbound rules), the taxation of non-resident taxpayers earning income from South African sources (inbound rules), the headquarter company regime that touches on both inbound and outbound elements, and anti-avoidance rules. Part 4 analyses the intrinsic and drafting complexity of these

these amendments have not been organized into an 'official' consolidated version of the ITA. See A Sawyer, M Bornman \& G Smith 'Simplification lessons from New Zealand: Can they be relevant for South Africa' in C Evans, F Franszen \& E Stack (eds) Tax Simplification: An African Perspective (2019) 3.1.1. 
rules and attribute the former largely to international influences and the latter to drafting choices in South Africa. Part 5 offers some simplification (but not simplistic) ideas and urge South Africa to seriously consider rewriting the ITA to address both types of complexity.

\section{International tax environment}

\subsection{The notion of an international tax environment and its relevance}

The notion of an international tax environment is not well defined. It is used in this paper to refer to the international elements that affect the development and operation of international taxation. Some elements relate to international tax law and their general features. Some are business elements relating to business organisations in the form of multinational enterprises, business models for generating profits and tax-planning structures to minimise taxation. Other elements relate to institutions that lead or coordinated efforts to establish or reform international tax rules and norms, and the general political environment that shapes the development of international tax.

South Africa is influenced by the international tax environment because its economy is linked to the world economy and its tax base includes income from crossborder transactions. Although all taxes may be influenced (through tax transplants), the international tax rules are more affected. This is particularly true after South Africa switched from a territorial system to a worldwide system of taxation in $1994 .{ }^{9}$ In recent years, South Africa has participated in shaping the international tax environment, such as through the G20/OECD Base Erosion and Profit Shifting (BEPS) Project. ${ }^{10}$ The BEPS Project produced some new minimum standards to be adopted by countries and

\footnotetext{
9 TA Manuel, MP, Minister of Finance, South Africa 'The South African tax reform experience since 1994' at the Annual Conference of the International Bar Association www.treasury.gov.za/comm_media/speeches/2002/2002102501.pdf (visited on 18 September 2018); C. Evans and S-A Joseph 'The South African Tax System: Fit for Purpose?' (2015) vol.1:2 Journal of Tax Administration 25; AW Oguttu 'Ensuring a right balance in applying the residence and source bases of taxation in order to protect South Africa's tax base' in J Hattingh, J Roeleveld \& C West (eds.) Income Tax in South Africa: The First 100 Years (1914 - 2014) (JUTA 2016) Part 5.
}

10 For an overview of the BEPS Project and reports generated by the project, see http://www.oecd.org/tax/beps/ (accessed 18 September 2018). 
recommended measures to prevent tax avoidance, to require country-by-country reporting, among others. South Africa has already implemented some of the minimum standards and measures, which has undoubtedly added a layer of complexity to the ITA.

\subsection{Legal environment}

Taxation is governed by law, primarily by domestic laws and tax treaties. Tax sovereignty dictates that taxation is first and foremost a national competency, involving a deeply local (national) political issue / process. The idea of a "formal" international tax organization or convention is likely to be a distant dream - although probably not impossible - very unlikely in the near future. ${ }^{11}$

In the absence of an international tax organisation or convention, tax liability is established by national tax laws. Conflicts between national tax laws are resolved by way of bilateral tax treaties. Some of the general attributes of tax laws and tax treaties are widely accepted and form a critical part of the international tax environment.

\subsubsection{Tax sovereignty and interaction of national tax laws}

In accordance with the priorities established by the domestic political process, each country determines how much to tax and who to tax. With the increasing integration of domestic economies and the world economy, however, countries such as South Africa cannot ignore the tax systems of other countries if they want to remain competitive on the tax market ${ }^{12}$ in order to attract investments and promote economic development. As economic actors, states compete with one another for mobile capital and business activities through tax policy.

Countries have also entered into tax treaties to deal with the interaction of national tax laws to prevent double taxation and fiscal evasion. Currently, South Africa has

11 The work carried out in the framework of BEPS proves that the creation of supranational tax law is no longer an unrealistic scenario: RS Avi-Yohan 'A perspective of supra-nationality in tax law' in $Y$ Brauner \& P Pistone, eds. BRICS and the emergency of international tax coordination (IBFD 2015) 33-39.

$12 \mathrm{~T}$ Dagan International tax policy between competition and cooperation (2017) (noting the marketization of tax policy and states, as economic actors, use tax rules as currency of competition) 24-26. See also T Dagan 'The global market for tax and legal rules' (2017) 21 Florida tax revenue 148. 
concluded over 80 bilateral tax treaties, ${ }^{13}$ which is one of the largest treaty networks in the world. Although these treaties are based on the OECD Model Convention ${ }^{14}$ and the UN Model Convention ${ }^{15}$ and have the same structure and common provisions, they are not identical, reflecting the concerns of the two contracting parties. ${ }^{16}$

Both domestic law and tax treaties follow the same residence-source paradigm in allocating taxing rights: the residence country has the general and residual right to tax a taxpayer's income, while the source country has the primary, but limited, right to tax specific types of income. The residence country is obliged to provide relief for double taxation.

Legal transplantation is another important aspect of the international legal environment. Countries (both the legislature and judiciary) borrow rules or laws from other countries to reform their tax laws or to be consistent with the international tax norm. For example, South Africa adopted a residence-based tax system in 1994 to international experiences, ${ }^{17}$ reformed the transfer pricing rule in 1995 to be more consistent with Article 9 of the OECD and the UN Models, ${ }^{18}$ introduced the GAAR in 2006 after considering the GAARs in Australia, Canada, New Zealand, Spain, United Kingdom and the United States, ${ }^{19}$ and incorporated the country-by-country reporting rule (CBCR) and

\footnotetext{
13 See $\quad$ http://www.sars.gov.za/Legal/International-Treaties-Agreements/DTAProtocols/Pages/default.aspx (visited on 18 September 2018).
}

14 Organization for Economic Cooperation and Development, Model Tax Convention on Income and on Capital (OECD Model), available at http://www.oecd.org/ctp/treaties/model-tax-convention-on-incomeand-on-capital-condensed-version-20745419.htm (visited on 18 September 2018). The OECD Model was updated in 2017 to incorporate some of the BEPS project recommendations.

$15 \quad$ United Nations Model Double Taxation Convention between Developed and Developing Countries (UN Model), at www.un.org/esa/ffd/wp-content/uploads/2018/05/MDT 2017.pdf (visited on 18 September 2018). The UN Model was also updated in 2017 to incorporate some of the BEPS project recommendations.

16 South Africa signed the Multilateral Convention to implement tax treaty related measures to prevent base erosion and profit shifting (MLI) in June 2017, which will have the effect of amending selected bilateral tax treaty provisions.

$17 \quad$ Manuel, n 9 above, 6.

18 C Bruyn \& L Möller 'South Africa branch report' in (2017) IFA cahiers de droit fiscal international 689.

19 T Calvert 'The consequences of adapting tax legislation, using international standards in the developing worlds: A South African example' (2012) Australasian Tax Teachers Association Conference 1 (unpublished, on file with the authors); TMC Pidduck 'The South African general anti-tax avoidance rule 
limitations on interest deduction and the hybrid rules recommended by the BEPS Project. Judicial borrowing also takes place in South Africa, for example, the courts have recognised the choice doctrine and statutory interpretation doctrines (i.e. taxing statutes should be given a largely literal interpretation and transactions should be characterised according to their legal form and substance, as opposed to their economic substance). ${ }^{20}$ Since tax treaties generally follow the model conventions, South African courts sometimes consider cases in other jurisdictions. ${ }^{21}$

\subsubsection{International tax rules are more complex}

The international aspects of a country's tax system tend to be more complex for several reasons. First, the taxpayers have more complex situations in terms of their affiliation with the country: some are local residents and others are foreign residents. Resident taxpayers do business overseas or hold investments in entities in low-tax jurisdictions that do not share taxpayer information with the residence country. Foreign residents can be MNEs whose capital and technology are deemed important to the host country or MNEs who use aggressive tax planning to minimise taxes.

Second, taxpayers' transactions are more complex, especially those between members of the same MNE group or between related parties. The transfer pricing rules that apply to these transactions are among the most complex.

Third, to prevent double taxation and tax avoidance and remain competitive, a country's tax law must consider the tax laws of other countries. This unique aspect of international taxation is inherently more complex as the domestic law must consider whether and when to cede tax jurisdiction to another country (through foreign tax relief measures).

and lessons from the first world: A case law approach' (unpublished PhD thesis, Rhodes University, 2017, on file with the authors) 4 .

20 A Oguttu 'South Africa' in M Lang et al. (eds) GAARs - A key element of tax systems in the postBEPS world (2016) 611.

21 I du Plessis 'Some thoughts on the interpretation of tax treaties in South Africa' (2012) 24 South Africa Merc Law Journal 31. 
Most importantly, international tax rules might be more complex because of the divergence in domestic tax laws and the general legal systems. Tax law sits atop of, or is accessory to, general (or non-tax) law as it defers to the latter for establishing, among other things, what is a corporation, the legal nature of a transaction giving rise to revenue or deductible expenses, and where the transaction takes place. This accessory nature of tax law gives rise to additional challenges in the context of international taxation, owing to the divergence in the general legal systems. For example, the law that gives legal 'fictions' such as corporations a life and existence distinct from their economic owners, may differ from the corporate law in the country where a corporation carries on its business. A corporation (for example a branch or partnership) that is distinct from its owners in one country may be a direct manifestation of its owners in terms of the private law and tax law of another. A share may be treated as equity in one country, but as debt in another. In general law, such divergence leads to the so-called hybrid entities (i.e. entities that are seen as corporations in one country, but as partnerships in another), or hybrid instruments (e.g. financial instruments that are seen as debt in one country, but as equity in another). International tax rules wrestle with such divergent issues. Ultimately, the policy question is whether the legal fiction gives the country of incorporation the right to tax, as opposed to giving that right to the country in which the shareholders or businesses are situated. Different countries may have different answers to this question.

\begin{abstract}
As the BEPS Project forcefully shows, given the absence of necessary or effective homogeneity of or coordination among countries' laws, "hybridity" can reflect perfectly legal commercial and other arrangements that simply, by force of circumstance, result in no tax being paid anywhere while fully complying with all relevant laws. That outcome draws attention to what the "international tax bargain" among countries really is, a question that is made even more difficult in an increasingly "globalized" world where connections of taxpayers and income earning activities to particular countries is not infrequently hard to detect according to prevailing "international tax rules" and their reliance on observable and often "physical" connections of this sort. ${ }^{22}$
\end{abstract}

\title{
2.2.3 The rise of anti-avoidance rules
}

A notable phenomenon in international taxation is the rise of anti-avoidance rules over the last few decades. These rules typically deny the tax benefits (such as tax deductions 
or exemptions) that would otherwise be available to the taxpayer through using tax planning structures. These structures are typically designed to take advantage of the fact that tax law relies on general law (such as corporate law or contracts) for the characterization of transactions for tax purposes, the form over substance doctrine in statutory interpretation, textual interpretation of tax legislation, or gaps between national tax laws. For example, the controlled foreign corporation (CFC) rules deny the benefit of tax deferral through using a foreign corporation to hold investments; the transfer pricing rules deny the tax reductions resulted from artificial prices set by contracts between related parties; the hybrid rules deny the benefits of arbitraging the different tax treatment of the same transaction in two countries. The BEPS Project has generated more antiavoidance rules (such as the principal purpose test) to ensure that profits are taxed in the country where economic activities take place and value is created.

Most of these rules are 'surgical' in that they address specific types of tax arrangements (debt financing and the use of holding companies or treaty shopping) and are often called specific anti-avoidance rules (SAARs). Typically, they must first describe the mischief (or offensive type of tax avoidance arrangement) and then remove the mischief without affecting the operation of the basic rules or other SAARs, or interfering with legitimate business arrangements. They are inherently complicated.

While expressing which specific tax arrangements are not acceptable, SAARs may also signal to taxpayers that what is not prohibited is permitted. In order to protect the general integrity of the tax law, a general anti-avoidance rule (GAAR) has been introduced by many countries, including South Africa. A GAAR is drafted as a standard, as opposed to a rule. As such, the wording of a GAAR provision may not be complex, but its application is often unpredictable and perceived by some as a 'sword of Damocles' that favours the government. ${ }^{23}$ A GAAR is not self-executing and often takes a great deal of

23 A Marais 'South Africa' IFA cahiers de droit fiscal international (2018) - Anti-avoidance measures of general nature and scope - GAAR and other rules. 
time for the government to litigate a GAAR case, thereby creating a sense of uncertainty. ${ }^{24}$

\subsection{Business environment}

Changes to international tax law have often been driven by changes in the business world. In fact, the need for tax legislation to respond to changes in respect of business models and tax planning strategies is a significant cause of tax complexity. This is evidenced by the BEPS Project.

The ways in which MNEs earn profit have changed dramatically and will continue to change. The traditional model of full-function subsidiaries engaged in manufacturing or distribution is being replaced by single-function entities conducting contract manufacturing and research, and development and distribution through commissionaire arrangements. Thanks to globalisation and advancements in communications and other technologies, the business of MNEs is fragmented across countries, producing profit through a global value chain. For MNEs, the world has shrunk and national boundaries, in a political/fiscal sense, are of limited importance. In the new global economy, returns on the deployment of productive resources are much less clearly associated with physical circumstances or geographical locations that influence how those returns are generated. The income and the imperatives that define an organisation's location are becoming 'stateless'. These changes have rendered many existing tax rules ineffective or difficult to apply. One example of this is the area of transfer pricing, which depends on transactional analysis and finding the elusive arm's-length transactional price.

Increasing globalisation has brought with it increased intangibility of cross-border transactions in the form of digital or information products, intangible property and services. For example, the value of the intangible assets of the value of S\&P 500

24 In South Africa, there have been no court decisions on the amended GAAR. Experiences in other countries show that judicial interpretation of the GAAR does not necessarily make the application of the rule more predictable, but it shines light on the types of "abusive" avoidance transactions. See J Li, T. Hwong et al 'GAAR in Action: An Empirical Exploration of Tax Court of Canada Cases (1997-2009)' (2013) Canadian Tax Journal 321; GT Pagone, Tax Avoidance in Australia (2010); and Oguttu, n 21 above. 
companies was $17 \%$ in $1975,32 \%$ in 1995 and $84 \%$ in $2015 .{ }^{25}$ To MNEs, intangibles are the source of a unique but invisible implied return from being an economic firm operating as a constellation of legal entities connected by transactions. The value of intangibles is difficult to estimate, and it is even more difficult to pinpoint the assets to a particular geographic location. The current tax systems are poorly equipped to deal with intangibles since they assume that legal entities 'do things' in 'particular places'. This is one of the issues that the BEPS Project attempted to tackle.

A more obvious example is the rapid rise of a digital economy. In this new economy, customers and users of digital businesses such as FAANGU (Facebook, Amazon, Apple, Netflix, Google and Uber) play a critical role in value creation. There is a paradigm shift from how value was created in the pre-digital world. In traditional businesses, value is realised when goods or services are sold to customers, not created by them. This shift is disrupting the existing tax rules, which focus on the MNEs' activities and assets. New rules have been proposed to tackle this challenge. ${ }^{26}$

MNEs have always used strategies to minimise taxation. ${ }^{27}$ More recently, however, the new business models, digitisation and integration of national economies have been accompanied by more aggressive tax planning strategies.

A range of new tax-planning opportunities were opened up by the carving up of value-adding activities among MNE legal entities in line with the new business model [global value chain]. The necessarily greater volume and variety of intercompany transactions, arising from having one subsidiary carry out functions for a range of subsidiaries which previously carried these out separately, also gave rise to tax planning opportunities. These key operations, which typically only required a handful of staff, could be located in low-tax jurisdictions. This was facilitated by the "un-bunching" of MNE value-creation activities from the MNE parent company and from key subsidiaries in high-tax jurisdictions. ${ }^{28}$

25 http://www.oceantomo.com/2015/03/04/2015-intangible-asset-market-value-studyl (accessed 18 September 2018) 'Annual Study of Intangible Asset Market Value from Ocean Tomo.

$26 \quad$ OECD tax challenges arising from digitisation - Interim Report 2018.

$27 \quad$ M Durst 'Poverty, tax competition, and base erosion tax' Notes International (19 March 2018) 1189.

28 C Turly, D Chamberlain \& M Petriccione A new dawn for the international tax system: evolution from past to future and what role will China play? (IBFD 2017) 102. 
Many of these practices have been targeted by the BEPS Project and domestic antiavoidance rules. ${ }^{29}$

\subsection{Institutional environment}

There is no single international organisation that oversees international tax issues. At the moment, several international institutions are involved: the OECD, the United Nations (UN), the International Monetary Fund (IMF), the World Bank and the European Union (EU). Groups of countries, such as the G20 and BRICS (Brazil, Russia, India, China and South Africa) countries, are also involved.

The OECD has been the de facto world tax organisation since its predecessor took over the work of the League of Nations in developing model tax conventions. ${ }^{30}$ The OECD also publishes guidelines on transfer pricing that are widely used in OECD and nonOECD countries. The OECD has worked with the G20 in championing the BEPS Project. The UN has developed a model convention ${ }^{31}$ and published a manual on transfer pricing for developing countries. ${ }^{32}$

Other organisations or groups have not published specific tax-related documents or guidelines. The G20 countries were instrumental in initiating the BEPS Project in 2013. In 2016, the IMF, the OECD, the UN and the World Bank Group launched the Platform for Collaboration on Tax (Platform) to intensify cooperation on tax issues between these organisations. ${ }^{33} \mathrm{~A}$ major aim of the Platform is to better frame technical advice to developing countries as they seek both more capacity support and greater influence in

29 See headings 2.2.3 above and 3.6 of this chapter.

30 Global Tax Treaty Commentary 'History of Tax Treaties' IBFD Tax Research Platform (visited on 18 September 2019).

31 OECD Model, n 14 above.

32 United Nations practical manual on transfer pricing for developing countries (UN 2017) (UN Manual).

33 http://www.oecd.org/ctp/platform-for-collaboration-on-tax.htm. (Accessed on 18 September 2018) 
designing international rules. ${ }^{34}$ The BRICS block has included taxation matters in its mandate, but no formal unified tax position has yet been released. ${ }^{35}$

\subsection{Political environment}

It is not unusual for political factors to shape the tax policies of some countries, and major tax reforms in countries such as the United States often find their way into the tax policies of other countries through tax law borrowing. ${ }^{36}$ Political pressures arising from the popular outcry against tax avoidance by MNEs following the 2008 global financial crisis helped launch the BEPS Project. ${ }^{37}$ The BEPS Project has increased global consciousness, even self-consciousness, about the meaning and significance of international tax accommodations among countries. It has also elevated international tax reform from closed-door discussions among tax experts and policymakers to a level of political debates. Tax reforms, especially those affecting international tax relations, cannot be isolated from international political influences.

\section{International tax system in South Africa}

\subsection{International aspects of the Income Tax Act, 1962}

The ITA ${ }^{38}$ imposes taxes on all persons, including individuals ${ }^{39}$ and companies. It is the main instrument for raising revenues to fund expenditure in support of social programs. It is also an instrument for promoting economic growth and attracting foreign investment. ${ }^{40}$

\footnotetext{
$34 \quad$ The Platform published a report on the "Taxation of Offshore Indirect Transfers of Assets" in 2018.

$35 \quad$ Brauner \& Pistone, n 11 above.

$36 \quad \mathrm{~V}$ Tanzi 'The response of other industrial countries to the US Tax Reform Act' (1987) 40 National Tax Journal 339.

37 I Grinberg 'The new international tax diplomacy' (2016) 104 Georgetown Law Journal 1137.

38 The ITA contains provisions for different types of income tax: normal tax, donations tax, dividends tax and withholding taxes.

$39 \quad$ Issues associated with personal income tax are beyond the scope of this paper. For a discussion of the simplification of the personal tax, see Steyn \& Stiglingh (n 1 above) 157.

$40 \quad$ National Treasury '2018 Budget Review' 41; South Africa, National Treasury, 'Medium-term Budget Policy Statement 2017', at iii; '2018 Budget Review', ed. National Treasury (Pretoria: Government Printer, 2018), vii. Also see Davis Tax Committee reports (n 2 above). For an excellent overview of the international tax system in South Africa, see J Hattingh 'South Africa' in Brauner \& Pistone, n 11 above, 213-270.
} 
The statute is organised into chapters and many chapters are organised into parts. Basic provisions are organised into sections. International tax rules are found mostly in different parts of Chapter 2, such as Part 1 (Normal tax), Part 2 (Special provisions relating to companies), Part 3A (Taxation of foreign entertainers and sportspersons), Part 4A - Part 4C (Withholding tax on royalties, interest and service fees), and Part 7 (Dividends tax).

The ITA does not have specific charging provisions. The inbound rules are scattered in different places of the ITA. The same is true for outbound rules and antiavoidance rules. For purpose of discussion, we group these rules as follows:

- Jurisdiction to tax: section 5 (levying of normal tax and tax rates) and section 1 (definitions);

- Inbound rules: section 9 (source of income); section 35A (withholding tax on capital gains); sections 47A-47K (tax on foreign entertainers and sportspersons); sections $49 \mathrm{~A}-49 \mathrm{H}$ (withholding tax on royalties); sections $50 \mathrm{~A}-50 \mathrm{H}$ (withholding tax on interest); and section 64G (withholding tax on dividends); ${ }^{41}$

- Outbound rules: section 6 (normal tax rebates); section 6quat (rebate or reduction in respect of foreign taxes); section 6quin (rebate in respect of foreign taxes on income from sources within the Republic); and section 64N (rebate in respect of foreign taxes on dividends);

- Specific anti-avoidance rules: section 9D (controlled foreign companies); section 20C (ring fencing of interest and royalties incurred by headquarter companies); section 31 (arm's- length principle); sections 8E, 8F and 8FA (hybrid instruments); and section 23I (round-tripping of intellectual property);

- GAAR: sections 80A-80L; and

- Tax incentives: section 9I (headquarter companies); section 10B (exemption of foreign dividends and dividends paid or declared by headquarter companies); and section 12R (special economic zones).

$41 \quad$ Proposed sections 51A-51H (withholding tax on service fees) were withdrawn in 2017, which would have made South Africa one of the first countries to impose a final withholding tax on services fees and take advantage of the new Article 12A of the UN Model. 


\subsection{Tax jurisdiction}

The ITA has a rather interesting way of stipulating the scope of tax jurisdiction. Section 5(1) states:

... [t]here shall be paid annually ... an income tax ... in respect of the taxable income received by or accrued to or in favour of

(c) any person (other than a company) during the year of assessment ...; and

(d) any company during every financial year of such company.

Other than stating that a company is liable to be taxed annually on its taxable income, section 5 makes no reference to the international aspect of taxing corporations or residence-source paradigm mentioned earlier. The paradigm is well hidden in the definition of gross income, which is the basis for computing 'taxable income. Section 1 defines gross income as follows:

i. in the case of any resident, the total amount, ... received by or accrued to or in favour of such resident; or

ii. in the case of any person other than a resident, the total amount, ... received by or accrued to or in favour of such person from a source within or deemed to be within the Republic ... (Emphasis added.)

Through its definition of gross income, the ITA imposes tax on a resident's total income (regardless of source) and a non-resident's income from a source in South Africa. This is consistent with the international tax paradigm. Other sections elaborate on the notions of residence and source of income.

Section 1 also defines a company's residence in South Africa by referring to its incorporation or place of effective management in this country and clarifying that an otherwise resident company is deemed to be a non-resident if it is a resident in a treaty country. For practical purposes, a foreign-based MNE investing in South Africa is likely to incorporate a local subsidiary. Under the headquarter company or HQC regime, a local subsidiary may also be used to invest in other countries and enjoy the tax exemption on foreign-source income. 
The notion of source is undefined in the ITA, but section 9 provides deeming rules for rent, royalties, dividends, interest, service fees, pensions and annuities, and capital gains. ${ }^{42}$ Case law offers some guidance on the meaning of source. For example, in the case of CIR v. Lever Bros \& Unilever (1946) ${ }^{43}$ it was held that the word source referred to the originating cause of income and that the originating cause of income was the income-earning activity or work done (in the case of active income), or the property, or its use (in the case of income derived from granting the use of property). Whether the source is in South Africa is established by way of a facts and circumstances test. For example, in deciding whether a taxpayer carried on business in South Africa, relevant factors include: the degree of continuity, the profit-making motive, the frequency of the business and the facts surrounding the matter. ${ }^{44}$

\subsection{Outbound rules - resident companies earning foreign income}

\subsubsection{Policy goals and technical issues}

The rules applicable to resident companies that earn income from sources outside South Africa seem to aim at achieving several tax policy goals, such as facilitating outbound investments by South African companies by preventing double taxation of foreign income, while simultaneously minimising the avoidance of South African tax through using foreign corporations, offshoring locally developed intangible property or importing foreign losses. In addition, these rules and the HQC regime work together to promote South Africa as a regional headquarter jurisdiction for foreign-based MNEs.

The many important technical issues that are involved in drafting outbound rules will be discussed in more detail below. The three more general issues are: (1) How to recognise a foreign tax as equivalent to that imposed under the ITA for foreign tax relief purposes in order to prevent double taxation. (2) To what extent should the ITA respect the legal separation of foreign income from its ultimate owner - a South African resident - through using a foreign corporation? Should the mere legal separation be ignored for

\footnotetext{
$42 \quad$ See heading 3.4 .3 below.

$43 \quad 14$ SATC 1.

$44 \quad$ CIR $v$ Kuttel 1992 (3) SA 242 (A), 54 SATC 298.
} 
ITA purposes, but not in all cases, and how should the line be drawn between the two scenarios? These issues frame the CFC rules. (3) How to ensure that double tax relief rules and CFC rules are coherent in promoting South Africa's policy goals, including those underlying the $\mathrm{HQC}$ regime.

\subsubsection{Foreign tax relief}

The ITA recognises foreign taxes paid by residents on foreign income through exempting foreign income from tax, deducting foreign tax in computing taxable income, or rebating (crediting) foreign tax in computing South African tax liability. ${ }^{45}$

The exemption method is limited and applies only to certain types of foreign income. For example, section $10 \mathrm{~B}(2)$ (a) provides for a so-called participation exemption rule according to which dividends received from a non-resident company are exempted from tax if the shareholder is resident in South Africa (whether alone, or together with another company forming part of the same group of companies) and holds at least $10 \%$ of the total equity shares and voting rights in the non-resident company. ${ }^{46}$

The foreign tax deduction method applies only if the foreign taxes cannot be rebated. For example, a resident deriving taxable income from carrying on any trade in a foreign jurisdiction may deduct foreign income taxes, except when foreign taxes on income qualify for foreign tax rebate under section 6quat(1C). Furthermore, the amount deducted may not exceed the South African total taxable income (before taking into account this special tax deduction) that is attributable to income that was subject to the foreign tax sought as a deduction (section 6quat(1D)).

A foreign tax rebate or credit is the main method. The idea behind this method is simple: a foreign tax is viewed as the equivalent of domestic tax and offsets domestic tax otherwise payable. As a result, a taxpayer pays tax on the foreign income at a rate that

\footnotetext{
45 These measures are important under the current worldwide tax regime. Under the previous, primarily territorial system of taxation that did not seek to tax foreign income, these rules were less important.

46 For similar rules in other countries, see Canada Income Tax Act, R.S.C. 1985, c.1 (5 ${ }^{\text {th }}$ supp.) (Canadian ITA), section 113(1)(a) and United States, TCJA, P.L. 115-97, section 355 of Internal Revenue Code.
} 
is the higher of foreign tax rate or the domestic rate. Section 6quat stipulates the key requirements for this rebate, which include answers to the following questions: Who is eligible for the tax rebate? Which payments are in the form of foreign taxes? What income is derived from a foreign source? How much credit can be claimed? How can foreign taxes be translated into domestic taxes? How should one interact with the double tax method under an applicable tax treaty? Generally speaking, income taxes paid in a country that has a tax treaty with South Africa qualify for the tax rebate. The amount of creditable foreign taxes is limited by the amount of South African tax otherwise payable on the foreign income, and any excessive amount can be carried forward.

In the case of resident companies earning foreign income, foreign tax relief methods depend on whether the foreign income is earned directly through a branch or partnership, or indirectly through a foreign subsidiary. In the case of direct income, a foreign tax rebate is available. When a foreign subsidiary is used, the subsidiary is a nonresident in South Africa and is not taxable on its income under the ITA. Dividends paid by the subsidiary to the South African shareholder may be exempt from tax under section 10B (see above). ${ }^{47}$ However, if a foreign subsidiary is a CFC, its "net income" may be imputed to the South African shareholder under the CFC rules and the associated foreign taxes are, in effect, rebated. The goal of the CFC rules is to treat the tainted CFC income as earned directly by the shareholder for tax purposes.

\subsubsection{Controlled foreign corporations (CFCs)}

The CFC rules are often regarded as anti-avoidance rules, even though they are fundamental to the outbound regime in order to ensure that residents cannot avoid paying tax on foreign income by using a foreign company to legally separate their income from themselves. Since South Africa switched to a residence-based tax system, these rules have obviously become important locally. The CFC rules are among the most complex in both South Africa ${ }^{48}$ and other countries as they rely on technical rules to establish

\footnotetext{
$47 \quad$ This means that any foreign withholding tax paid on the dividends or underlying foreign corporate tax are not recognized in South Africa.

$48 \mathrm{~J}$ Hattingh 'South Africa corporate taxation' IBFD Tax Research Platform 10.4 (visited 18 September 2018).
} 
boundaries between the legitimate use of foreign companies and other uses in order to protect South Africa's tax base without impeding outbound investments or causing overtaxation of foreign income. In South Africa, these rules must also work in tandem with the HQC regime.

The idea of the CFC regime under section 9D is simple: any net income (sometimes known as tainted income) of a CFC is imputed on a proportional basis to the South African resident shareholder in the year in which the income is earned. In effect, the shareholder is deemed to have earned the CFC income directly. Thus, the normal tax benefit of using foreign corporations is denied.

The technical rules are complex as they must provide answers to questions such as: What is a CFC? What income of the CFC is tainted? How is tainted income computed, and how is it imputed to a specific shareholder resident in South Africa? How is relief provided for foreign taxes paid in respect of the imputed income? How do we identify that the use of CFC is for tax avoidance purposes? How should the dividend and capital gains regimes be reconciled when shares of a CFC are disposed of? How can economic double taxation be prevented when dividends are actually received out of income that has been taxed previous on an imputation basis?

Section 9D defines a CFC as a non-resident company in which one or more South African residents (natural and legal persons) directly or indirectly hold more than $50 \%$ of the participation rights ${ }^{49}$ or voting rights exercisable in the company. ${ }^{50}$ The key is to determine whether the corporation is controlled and presumably functions as a taxavoidance vehicle.

The tainted CFC income is essentially its non-business income (such as dividends, interest, royalties or rental) received from arm's-length parties. Such income is

\footnotetext{
49 Participation rights are defined under section $9 \mathrm{D}(1)$ as the right to participate, directly or indirectly, in the share capital, share premium, current or accumulated profits or reserves of the company, whether or not of a capital nature.

50 The CFC definition was expanded as of 1 January 2018 to include any foreign company where the financial results of that company are reflected in the consolidated financial statements of any South African resident company. This is to capture arrangements where a resident company uses foreign trusts or foundations to avoid the status of having a CFC. See Hattingh (n 48 above).
} 
presumably footloose and has no intrinsic reason to be sourced outside South Africa for tax purposes. Section 9D(2A) defines the net income of a CFC as the amount determined in a manner that is nearly identical to that used for a resident company and providing specific exclusions and limitations. One major exclusion is income attributable to a foreign business establishment, excluding non-genuine business transactions that effectively divert or shift South African income offshore (the so-called diversionary transactions under section $9 \mathrm{D}(9 \mathrm{~A})$ ). Intragroup payments of dividends, interest, royalties and rent or similar income are also excluded.

CFC rules do not apply to a foreign corporation that earns business income, is a public company or located in a high-tax country, since the use of the corporation is not presumed to be tax motivated. To determine whether a foreign country's tax rate is high, it is measured against the South African tax (if the foreign tax is at least $75 \%$ of the amount of South African tax that would have been payable had the CFC been a South African taxpayer).

The CFC rules interact with foreign tax relief rules to ensure that any foreign taxes attributed to the imputed CFC income are recognised under section 6quat. When the imputed CFC income is subsequently paid to the South African resident as dividends, such dividends are eligible for exemption under section 10B. The CFC rules complement the HQC regime by not applying to HQCs.

\subsection{Inbound rules: non-resident companies earning domestic income}

\subsubsection{Policy goals and technical issues}

The primary policy goals of inbound rules appear to be to generate tax revenue, achieve tax neutrality between residents and non-residents, and encourage foreign investment. To protect the tax base, the ITA contains anti-avoidance rules (see heading 3.6 below). Withholding of tax at source is used to ensure the effective collection of taxes from nonresidents who may have no physical assets or presence in South Africa.

The main technical issues are concerned with determining when income has its source in South Africa, whether withholding tax should apply to the South African source income, and whether special rules should be designed for payments to non-residents who 
are related to the resident payer. ${ }^{51}$ Most of the inbound rules in the ITA deal with withholding taxes. No specific provisions govern the normal tax liability of non-resident companies doing business in South Africa.

\subsubsection{Business income and normal tax liability}

The ITA does not define business or source of business income per se. Section 1 defines trade as including business. It appears that case law is the primary source of law relating to whether a non-resident earns business income from a South African source. Nonresidents earning business income in South Africa, for example by rendering technical or other services, are required to register and account for tax on income arising from a South African source. In practice, however, because South Africa has a broad network of tax treaties, the treaty threshold of permanent establishment (PE) replaces the domestic source rules. Section 1 of the ITA defines permanent establishment by referring to Article 5 of the OECD Model Convention.

South African source business income is subject to normal tax at the standard corporate tax rate. In computing taxable income for purposes of section 5 of the ITA, a non-resident seems to be generally entitled to the same deductions for costs and expenses. In effect, as far as South African source business income is concerned, a PE and local company are treated similarly, which reflects tax neutrality. ${ }^{52}$

\subsubsection{Withholding taxes}

Final withholding taxes apply to royalties (Part IVA), interest (Part IVB) and dividends (Part VIII). A provisional withholding tax applies to capital gains on the disposition of immovable property in South Africa (section 35A). The tax rate is 15\% on interest and royalties, $20 \%$ on dividends and $10 \%$ on capital gains. ${ }^{53}$

\footnotetext{
51 The inbound rules are often modified by tax treaties. However, it is beyond the scope of this chapter to examine the interaction between the ITA and South Africa's tax treaties.

52 Unlike a local subsidiary of a foreign company, however, repatriation of after-tax profits of a permanent establishment is not subject to withholding tax, but dividends paid by a subsidiary to its foreign parent are subject to such a tax. The ITA does not have a branch profit tax, as is found in Canada (section 219 of the Canadian ITA).

53 For further discussion, see T Koole 'South Africa Branch Report' (2018) IFA Cachiers de droit fiscal international: Withholding tax in the era of BEPS, CIVs and the digital economy.
} 
Two key technical issues are the characterisation of a payment and source rules. The ITA defines the key concepts and source rules. For example, section 1 defines dividends and sections $50 \mathrm{~A}$ and $24 \mathrm{~J}(1)$ define interest. These statutory definitions are generally extensive. Section 49A defines royalty as any amount in respect of: (a) the use of, or the right of use of, or permission to use any intellectual property; (b) the imparting of any scientific, technical, industrial or commercial knowledge or information (often known as know-how); or (c) the rendering of a service in connection with the application or utilisation of know-how (show-how services). ${ }^{54}$

Section 9 provides the following source rules:

(a) Dividends have a South African source if the payer company is resident in South Africa (see section 9(2)(a) and the definition of dividends in section 1).

(b) Capital gains from immovable property have a South African source if the property is situated in South Africa ${ }^{55}$ (section 9(2)(j)).

(c) Interest and royalties have a South African source if:

- the payer is a South African resident, unless the amounts are attributable to a permanent establishment outside South Africa (for example, interest paid by a South African company to a foreign bank on a loan used to finance the operation of a permanent establishment in Canada) (section 9(2)(b)(i) and (c)), or

- the use of the debt or intellectual property/know-how in South Africa (section 9(2)(b)(ii) and (d)).

(d) Know-how service fees have a South African source if a service is rendered in connection with the use of know-how in South Africa (section 9(2)(f)).

\footnotetext{
54 The terms know-how and show-how services are not used in the ITA. They are used in this chapter for easy reference.

55 Shares of a company are treated the same if $80 \%$ of the value of the shares is attributable to immovable property in South Africa (sections 35(15) and 2(1)(b) of the Eighth Schedule to the ITA).
} 
The source rules for dividends, interest and royalties rely on the residence of the payer. ${ }^{56}$ Unlike dividends, interest, royalties and service fees are typically deductible expenses for the payer, regardless of whether the payer is a resident or non-resident earning South African source business income through a permanent establishment. As such, the source rules refer to the use of debt capital or intangible property (including know-how and technical services) in South Africa and function as base-protection rules.

\subsection{Inbound and outbound rules: headquarter company regime}

Headquarter companies are essentially resident companies that function as regional headquarters of MNEs. Through election they can qualify for preferential treatment, primarily in the form of being exempted from the various anti-avoidance rules and withholding taxes. ${ }^{57}$ The policy goal is to make South Africa a 'gateway to Africa', or an ideal location for MNEs to set up regional headquarters. ${ }^{58}$

Section 9 I sets forth the qualifying conditions for a HQC, which include that each shareholder in the company must hold at least $10 \%$ of the equity shares and voting rights; $80 \%$ or more of the company's assets (valued on a cost basis) are attributable to equity in, debt advanced to, or intellectual property licensed to a foreign affiliate; ${ }^{59}$ and at least $50 \%$ of the company's gross income consists of investment income (rent, dividend, interest, royalty) or a service fee paid or payable by a foreign affiliate. ${ }^{60}$

Preferential treatment of an HQC includes exemption from the application of the CFC rules (section 9D(2)); dividends, royalties and interest paid by an HQC to nonresidents are free from withholding taxes; ${ }^{61}$ capital gains realised on the sale of shares in

56 This rule is important for a withholding tax regime as the payer is liable to withhold tax from payments to non-residents and it is easier to enforce the obligation in the case of residents.

57 E Mzansky 'South Africa: new headquarter company regime' (March 2011) Bulletin for international taxation 166.

$58 \quad \mathrm{n} 57$ above.

59 We use foreign affiliate to refer to a non-resident company in which at least $10 \%$ of the equity shares and voting rights are held by the resident company (section $9 \mathrm{I}(2)(\mathrm{a})$ ). This term is relevant in the context of CFC rules and other rules.

60 This $50 \%$ rule applies only where the gross income exceeds R5 million.

61 Sections $49 \mathrm{D}$ (c) for royalties, section $50 \mathrm{D}(1)(\mathrm{a})(\mathrm{i})(\mathrm{aa})$ for interest, and section 64E for dividends. 
a foreign affiliate are tax-free; ${ }^{62}$ and certain transactions, between an HQC and its related companies are free from thin capitalisation and transfer pricing rules (section 31(5)). Interest and royalties expenses are, however, ring-fenced in the sense that they are deductible to the extent of interest and royalties received from qualifying investments in foreign affiliates. ${ }^{63}$ If an HQC earns any South African business income, it is liable for the payment of the normal tax on such income.

\subsection{Anti-avoidance rules}

\subsubsection{Policy goals and technical issues}

The ITA contains a GAAR and numerous specific anti-avoidance rules or SAARs. Presumably, like similar rules in other countries, these rules are intended to protect the tax base without unduly interfering with legitimate tax planning or causing unnecessary uncertainty. They have the effect of attenuating the so-called choice principle established in common law. ${ }^{64}$

A key issue in drafting anti-avoidance rules is defining the kind of avoidance transaction that is unacceptable from a policy perspective. The GAAR does this by using the notion of impermissible tax avoidance arrangements, which involve an inquiry into the purpose of the arrangements. A SAAR specifies a particular type of arrangement, such as transfer pricing, intragroup debt financing, hybrid instrument or controlled foreign corporations. These targeted transactions are often presumed to be tax motivated without an explicit purpose test. Another technical issue relates to the tax consequences, such as denying the tax benefit sought to be obtained by the taxpayer and corresponding adjustments to ensure the integrity of the tax system.

By design, the GAAR is more general and ambiguous than a SAAR. SAARs are more explicit and self-executing in the sense that taxpayers can avoid their application or

\footnotetext{
62 Eighth Schedule, paragraph 64B(2). Foreign exchange control rules and regulations do not apply to HQCs.

63 Any disallowed amounts can be carried forward.

$64 \quad$ IRC v Duke of Westminster (1936) 19 TC 490. Commissioner for Inland Revenue v Conhage (Pty) Ltd (formerly Tycon (Pty) Ltd) (1999) 61 SATC 391.
} 
know the tax consequences in advance. The GAAR is not self-executing and is only used by the tax administration as a shield to protect the tax base.

\subsubsection{GAAR}

The current GAAR is found in sections $80 \mathrm{~A}$ to $80 \mathrm{~L}$ of the ITA. ${ }^{65}$ These provisions are fairly detailed. Section 80(A) defines impermissible tax avoidance arrangements and section 80B spells out the tax consequences of such arrangements. Other sections offer more detailed guidance on these two basic provisions.

Under section 80A, an avoidance arrangement is an arrangement that results in a tax benefit. An impermissible avoidance arrangement is an avoidance arrangement which has the "sole or main purpose" of obtaining a tax benefit and falls into one of the following scenarios: it lacks a bona fide business purpose or commercial substance; ${ }^{66}$ 'it has created rights or obligations that would not normally be created between persons dealing at arm's length'; or 'it would result directly or indirectly in the misuse or abuse of the provisions of this Act' (including the GAAR provisions) (see the flow-chart below). ${ }^{67}$

65 It replaced section 103(1) of the ITA of 1962, which replaced section 90 of Tax Act 31 (1941). For further, see Marais n 23 above; Ogattu n 20 above; BT Kujinga 'General anti-avoidance rules in income tax legislation' (2014) Vol XLVII Comparative and International Law Journal of Southern Africa 429; SARS Draft Comprehensive Guide to the General Anti-Avoidance Rule (13 December 2010).

66 In a non-business context, the test is the lack of a bona fide purpose (section $80 \mathrm{~B}(\mathrm{c})$ ).

67 Section $80 \mathrm{~B}(\mathrm{c})$. Sections $80 \mathrm{C}-80 \mathrm{G}$ provide supporting guidance regarding the meaning of lack of commercial substance, round-tripping financing, accommodating or tax-indifferent parties and presumption of tax avoidance purpose. 


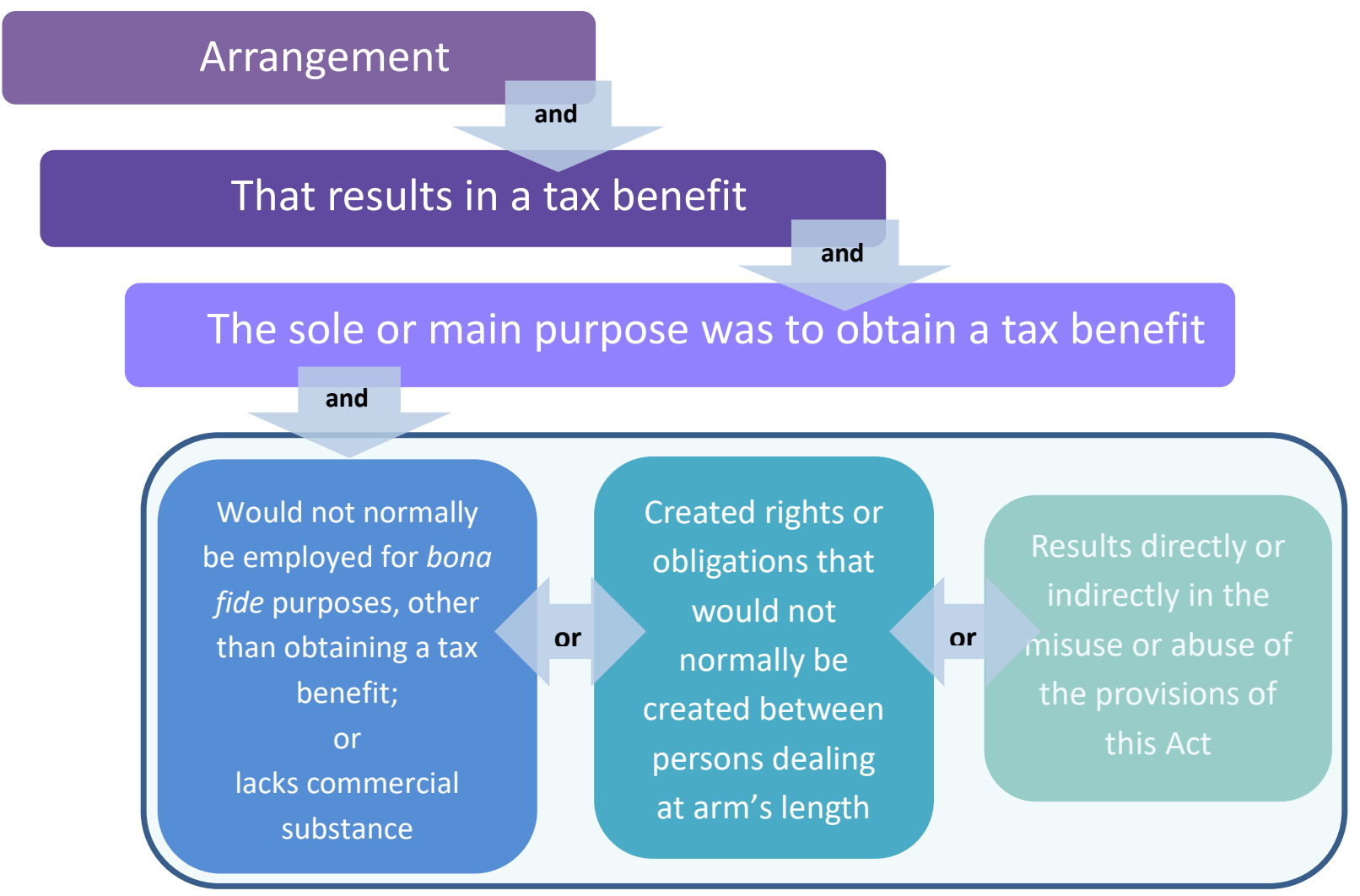

\section{Source: Authors' own illustration of the South African GAAR}

Once an avoidance arrangement exists, the GAAR provisions establish a two-step inquiry for determining whether the arrangement is impermissible:

Step 1: Is the main/sole purpose of an avoidance arrangement an attempt to obtain a tax benefit? ${ }^{68}$ If the answer is No, the inquiry ends. If the answer is Yes, go to Step 2.

Step 2: Is the transaction: (i) abnormal in the sense that it lacks a bona fide business purpose or has no counterpart in arm's length situations? (ii) artificial in the sense that it lacks commercial substance? or (iii) abusive in the sense that it results in the misuse or abuse of the provisions of the ITA 1962, including the GAAR provisions.

68 Section $80 \mathrm{G}$ places the burden of proof on the taxpayer and gives the Commissioner the benefit of doubt. 
If the GAAR applies to an avoidance arrangement, section 80B explicitly permits the Commissioner to take one or more of several measures, including to 'disregard, combine or re-characterise the arrangement or any step thereof'. The Commissioner can adjust the tax consequences nor only for the taxpayer who undertook the impermissible avoidance arrangement, but for any party, including a third accommodating party. ${ }^{69} \mathrm{~A}$ penalty may also be imposed. ${ }^{70}$

\title{
3.6.3 Transfer pricing
}

Transfer pricing rules in section 31 of the ITA codify the arm's length principle enshrined in the UN Model and article 9 of the OECD Model. Section 31 does not elaborate on the meaning and application of the arm's length principle. The South African Revenue Service (SARS) follows the OECD Transfer Pricing Guidelines (OECD Guidelines), ${ }^{71}$ even though it is acknowledged that some difficulties are encountered in doing so. ${ }^{72}$

Because of the incorporation of the OECD Guidelines, which occupy more than 600 printed pages and are frequently updated, the South African transfer pricing rules are, in practice, more extensive (and complex) that is conveyed by section 31 of the ITA.

Under section 31(2), the transfer pricing rules apply to any 'affected transaction' (essentially a transaction between 'connected persons'73 such as members of an MNE

\begin{abstract}
69 Sections $80 \mathrm{~B}$ and 80F.
70 See newly introduced S221 - S224 of the Tax Administration Act 28 of 2011.

71 SARS, Practice Note 2, 'Income tax: Determination of taxable income where financial assistance has been granted by a non-resident of the Republic to a resident of the Republic' (1996); SARS, Practice Note 7, 'Section 31 of the Income Tax Act, 1962 (the Act): Determination of the taxable income of certain persons from international transactions: Transfer Pricing' (1999) 6]. For further discussion, see W Horak 'South Africa, Transfer Pricing' in IBFD Tax Research Platform (visited 18 September 2018).
\end{abstract}

72 South Africa states the following in D.5.6.1 of UN Manual on Transfer Pricing, n 39 above:

The main challenge that South Africa has in determining arm's length profits has to be the lack of domestic comparables. ... The obvious problem this gives rise to has no simple or definitive solution. Instituting comparability adjustments to account for geographical differences (for example, market, economic and political differences) in order to improve the degree of reliability of the comparable data, is often extremely complex and can in some instances have the reverse effect, i.e. where the comparable data is no longer comparable.

73 The term connected person is defined in section 1. In relation to a company, a connected person is: any other company that would be part of the same group of companies (more than 50 per cent equity 
group) if any term or condition of that transaction results or will result in any tax benefit being derived by a person who is a party to that transaction. A typical transaction would be one entered into by a company in South Africa with its foreign parent or sister in respect of, among others, sales of goods, services, financing or licensing of intellectual property or know-how. Such transactions may result in an avoidance of South African tax if the resident company receives less or pays more than the arm's length price in respect of the affected transaction.

Determining the arm's length price (or the profit of the resident company) is at the heart of the arm's length principle. The OECD Guidelines provide five methods for making this determination: comparable uncontrolled price; resale price; cost plus; transactional profit method (TNMM); and profit split. ${ }^{74}$ It is beyond the scope of this chapter to discuss the details of these methods. Suffice it to say that these methods are not easy to apply as they require a transactional, comparative analysis of affected transactions and arm's length transactions, and are inherently inapt for unique transactions involving intangibles and services. In South Africa, it is often challenging for the SARS to obtain sufficient information to make the comparative analysis. ${ }^{75}$ The recent introduction of country-bycountry reporting $(\mathrm{CbCR})$ regulations attempts to address this challenge. ${ }^{76}$

Where the application of the transfer pricing rules results in an adjustment of the taxable income or tax payable by a taxpayer, section 31(2) allows for a corresponding adjustment for the other party to the same transaction. Moreover, the amount of adjusted income is deemed to be a dividend in kind. For example, if a South African resident borrows from a foreign parent and pays interest at the rate of $8 \%$ while the arm's length

ownership); any other company if at least $20 \%$ of the equity shares in the company are held by that other company and no shareholder holds the majority voting rights in that company.

74 It is beyond the scope of this paper to discuss the details of these methods. For further information, see UN Manual, n 32 above.

75 UN Manual, n 72 above.

76 This is to implement the recommendations BEPS Action 13 Report. When the ultimate parent entity of an MNE is a South African tax resident and has a consolidated group turnover of more than ZAR 10 billion (or, in certain circumstances, EUR 750 million), it must file a CbC report with SARS and notify them that it is the ultimate parent. 
interest rate is $6 \%$, the excessive interest paid is deemed to be a dividend for withholding tax purposes.

\subsubsection{Intragroup debt financing}

Intragroup financing is one of the common structures used by MNEs to shift profit from source countries. ${ }^{77}$ Sections 31 and $23 \mathrm{M}^{78}$ specifically limit interest expense deductions in cross-border situations. Interest arising in affected transactions within the meaning of section 31 is limited to the arm's length amount. ${ }^{79}$

Even if interest is paid at the arm's length rate, its deduction may be denied under section $23 \mathrm{M} .{ }^{80}$ Its purpose is to prevent the use of excessive intragroup debts in order to reduce the taxable income of the South African debtor. This provision limits the aggregate deductions for interest that is not subject to tax in the hands of the creditor who is in a controlling relationship ${ }^{81}$ with the debtor. This applies to a resident company or a nonresident with a permanent establishment in South Africa to which an interest-bearing debt claim is effectively connected. It does not apply if the interest is included in the imputed income of a CFC. In other words, section 23M aims at preventing base erosion through interest deduction.

The deduction limit is defined in section $23 \mathrm{M}(3)$ by reference to a percentage of adjusted taxable income. The percentage is defined by the formula:

$$
A=B \times C / D \text {, }
$$

where:

$A=$ the percentage to be determined;

$77 \quad$ Durst, $\mathrm{n} 27$ above.

$78 \quad$ It was introduced in 2013 and took effect in 2015, incorporating the recommendation in BEPS Action 4, 'Limiting Base Erosion Involving Interest Deductions and Other Financial Payments'. Some elements of limitation on interest deduction preceded the BEPS project and were borrowed from other jurisdictions, e.g. Germany.

79 Previously, SARS applied a 3:1 ratio in Practice Note 2, issued under the former transfer pricing regime, which functioned as a thin capitalisation rule.

$80 \quad$ Interest expenses in excess of the limitation will not be deductible, but the excess will be carried forward to the following year.

81 A controlling relationship exists if a person directly or indirectly holds at least $50 \%$ of the equity shares or $50 \%$ of the voting rights in a company (section $23 \mathrm{M}$ ). 
$B=$ the number 40 ;

$\mathrm{C}=$ the average repo rate plus 400 basis points; and

$\mathrm{D}=$ the number 10 ,

but the percentage cannot exceed $60 \%$ of the adjusted taxable income of the debtor.

The formula ensures that the percentage is adjusted according to changes in the Reserve Bank rate (average repo rate). ${ }^{82}$ The additional 400 basis points is a risk premium to account for volatility in the rand. For example, if the Reserve Bank rate is 6 percent, the limit will be 40 percent: $(40 \times(6$ percent +4 percent $)) / 10$. If the rate falls to 3 percent, the limit would be 28 percent: $(40 \times(3$ percent +4 percent $)) / 10$.

Adjusted taxable income is similar to the notion of EBITDA (earnings before interest, depreciation and amortisation) in the BEPS Action 4 Report. It is defined in section $23 \mathrm{M}(1)$ as the taxable income of the debtor determined under normal rules with some adjustments. One type of adjustment is to add back three items that are generally deductible in computing taxable income, i.e., interest, capital allowances and losses brought forward. Another type of adjustment is to exclude interest income received by the debtor, included CFC net income, and amounts recovered in respect of capital assets (or recaptures).

\subsubsection{Hybrid instruments}

Sections 8E, 8F and 8FA deal with cross-border financial instruments with mixed features of debt and equity in private law which, for tax purposes, may be characterised differently in South Africa than in another country. These instruments, which are covered by BEPS Action $2^{78}$, can be used to achieve the outcome of double non-taxation by taking advantage of the mismatch between the tax and private laws of different countries.

Section $8 \mathrm{E}$ targets equity funding with specific debt-like features, for example redemptions within prescribed periods; prescribed interest rate or the time value of money; and preference shares secured by financial instruments (e.g. interest-bearing

82 A Readhead 'Preventing Base Erosion: South Africa's Interest Limitation Rules' https://resourcegovernance.org/analysis-tools/publications/preventing-base-erosion-south-africa-interestlimitation-rules (accessed 18 September 2018). 
arrangements). ${ }^{83}$ Dividends on hybrid equity instruments are deemed to be income (as opposed to dividends) for the shareholder, and are therefore subject to normal tax rules. The effect is that the dividend exemption rules are rendered inapplicable.

Sections 8F and 8FA target hybrid debt instruments or hybrid interest and, for ITA purposes, deem interest to be dividends. A hybrid debt instrument is a debt instrument with equity features, such as convertible shares, subordinated loans and instruments with longer maturity dates. ${ }^{84}$ Hybrid interest is interest for which the amount is not determined by a specified rate of interest or the time value of money, or interest that is tied to the profits of the company. The effect of these rules is to deny interest deduction to the issuer of the instruments.

\subsubsection{Roundtripping of intellectual property}

Section 23I applies to what is known as roundtripping of intellectual property developed in South African ${ }^{85}$, but designed to shift income offshore. Typically, such property can be transferred to a related company in a no- or low-tax country outside the CFC regime, after which it can be licensed back to a company in South Africa in return for royalties. Royalties are generally tax deductible under the ITA.

Section 23I(2) prohibits any deduction for royalties or similar payments in respect of tainted intellectual property to the extent that under the ITA royalties do not constitute income to the recipient or part of imputed CFC. ${ }^{86}$ The notion of tainted intellectual property is thus key to this rule. Tainted intellectual property is at the heart of this antiavoidance rule. This term is defined in section 23I(1) to mean, essentially, intellectual

\footnotetext{
83 Hybrid equity instrument is defined in section $8 \mathrm{E}(1)$.

$84 \quad$ Section $8 \mathrm{~F}(1)$.

85 Section 23I(1) broadly defines intellectual property as a patent, design, trade mark or copyright; a property or right of a similar nature and knowledge connected to the use of such a patent, design, trade mark, copyright, property or right.
}

$86 \quad$ The withholding tax on royalties may be reduced under section $23 \mathrm{I}(3)$. 
property that was originally created and used in South Africa, but is owned by a related foreign company. ${ }^{87}$

Section 23 I works together with the transfer pricing rule in section 31 and the CFC rule in section 9D and was presumably enacted because these two rules were deemed insufficient. It is not easy to apply the transfer pricing rule to intellectual property since the arm's length price or market value of unique intellectual property is difficult to establish. Similarly, arm's length royalty rate may also be difficult to establish. As a result, a South African company (say SAco) developed a patent and received tax incentives for its research and development expenditures. While there was no market for it yet and it was free from transfer pricing assessment, SAco transferred the patent to a related foreign company (IPco) at nominal value. IPco made the patent available for use by other members of the corporate group, as well as to SAco or another related manufacturing company in South Africa (Opco). SAco and/or Opco pay royalties to IPco and deduct the payments in computing taxable income. IPco is outside the CFC regime if it is not a CFC (for example, being a sister company of SAco) or the royalties do not constitute net income for the CFC. As a result, the patent developed by SAco generates royalties that fall outside the South African tax system. If IPco is a CFC and pays dividends to SAco, such dividends are tax exempt under section $10 \mathrm{~B}(2)(\mathrm{a}) .{ }^{88}$

\section{Legislative complexity of the international tax system}

\subsection{Legislative complexity}

Legislative complexity may be measured by reference to such indicators as: a) whether the structure is clear; b) readability; c) coherency and consistency; d) effectiveness in achieving the intended policy goals. ${ }^{89}$ In our view, the international tax rules in the ITA

\footnotetext{
87 The South African end user or its connected person must hold at least 20 per cent participation rights in this foreign company.

88 In practice, as explained by Horak, $\mathrm{n} 71$ above, 9.8, it is very difficult to transfer intangible property rights to a connected person who is non-resident due to exchange control restrictions.

$89 \quad$ Tran-Nam (n 4 above); Tran-Nam et al (n 4 above) 349. Office of Tax Simplification (n 5 above); Davis Tax Committee, Closing Report (n 10 above).
} 
are complex. It lacks a clear structure that explicitly reflects the international tax paradigm, even though, it does so implicitly. We attribute this to drafting choices (see below). Many rules are not easy to read, owing to both the intrinsic technical difficulty and drafting techniques, such as excessive wording and long sentences. Many provisions may be viewed as incomprehensible by many taxpayers. ${ }^{90}$

We agree with Davis Tax Committee that: 'increasing complexity of corporate tax legislation (often influenced by international developments) has rendered the system more open to interpretation, less certain and less transparent'; 91 '[t]he overall complexity of the corporate income tax system is a cause for concern and simplification should be a priority'; ${ }^{92}$ and a 'tax system that people can understand is preferable to one that is complex and opaque'. ${ }^{93} \mathrm{We}$ attribute legislative complexity to the intrinsic reasons of international taxation, and thus necessary and unavoidable, and drafting choices that can be avoided.

\subsection{Intrinsic complexity}

The international tax rules in South Africa are intrinsically and necessarily complex for several reasons. First, they are generally more complex because of the taxpayers and taxable transactions to be addressed, the interaction of national tax laws and the divergence in the general law that underlies tax laws. ${ }^{94}$

Second, these rules can be perceived to be more complex in South Africa as they are mostly 'imported' due to the international tax environment. Even though compared to

\footnotetext{
90 See other papers in Evans, Franszen \& Stack, n 8 above, including: Sawyer, Bornman \& Smith, $n$ 8 above; B Tran-Nam, A Oguttu and K Mandy 'Overview of tax complexity and tax simplification: A critical review of concepts and issues' 4.5; S Smulders, K Stark, D Tickle 'Statutory and effective complexity for individual taxpayers in South Africa'; T Hoppe, R Safaei, A Singleton, C Sureth-Sloane 'Tax Complexity for Multinational Corporations in South Africa - Evidence from a Global Survey' 11.

91 Davis Tax Committee, Executive summary of the final report on macro analysis of the tax system and inclusive growth in South Africa 13.

92 Davis Tax Committee, The Tax System and Inclusive Growth in South Africa: Towards an Analytical Framework for the Davis Tax Committee: Executive Summary (June 2015) 28.

93 Davis Tax Committee, Executive summary of the final report on macro analysis of the tax system and inclusive growth in South Africa 5.

$94 \quad$ Heading 2.2 above.
} 
the systems of the OECD countries, the South African international tax system can be described as young or emerging, it contains most of the well-known anti-avoidance rules included in the developed tax systems that were designed to deal with sophisticated taxpayers (MNEs) and sophisticated tax planning strategies. Anti-avoidance rules are inherently complex as they must draw a line between acceptable and unacceptable tax planning. That often involves removing the 'normal' tax effect of using legal fictions and legal constructs that are otherwise accepted by tax law. For example, CFC rules negate the legal separation of income from its economic owner who is a South African taxpayer through the use of a legal fiction - a foreign corporation, but not in all cases. The effect of these rules is to "overrule" the tax effect of the corporate veil in respect of passive or diverted income that is otherwise taxed at a low foreign tax rate. CFC rules are among the most complex tax legislation in other countries, such as Canada. ${ }^{95}$

Third, some international anti-avoidance rules are principle-based and their application depends on international soft law or tax norms. One example is the arm's length principle in section 31 of the ITA and the implicit or indirect incorporation of the OECD Transfer Pricing Guidelines, which are generally accepted as soft law or international norms. ${ }^{96}$ Even though section 31 is not unusually lengthy or difficult to read, transfer pricing is the most difficult and challenging issue of international taxation. It "throws open a host of issues, the complexity and magnitude of which are often especially daunting for smaller tax administrations". ${ }^{97}$ These issues can be of technical nature in defining what transactions are subject to the arm's length principle and how to establish arm's length price for any type of transfer pricing transactions involve tangible goods, intangible property and unique services. In effect, the arm's length principle determines a MNE's taxable profit in a country by reference to "market prices" as opposed to those

\footnotetext{
$95 \quad$ Li \& Cockfield, n 22 above.

$96 \mathrm{~J} \mathrm{Li}$ 'Soft law, hard realities and pragmatic suggestions: Critiquing the OECD transfer pricing guidelines" in S Wolfgang and KA Konrad, eds. Fundamentals of International Transfer Pricing in Law and Economics (Springer 2012) 71; A Christians 'Hard Law \& Soft Law in International Taxation' (2007) vol 25 Wisconsin International Law Journal 214; and R Azam 'Ruling the World: Generating International Tax Norms in the Era of Globalization and BEPS' (2017) vol L Suffolk University Law Review 518.
}

$97 \quad$ UN Manual, n 35 above B.1.2.13 
established by legal contracts. More importantly, the transfer pricing rules determine South Africa's share of an international tax pie (i.e. the profit of a MNE) in a largely zerosum game and should be sufficient to enable SARS to "fight" with its counterparts in other countries for South Africa's share. Meanwhile, MNEs often use sophistically tax planning structures to avoid tax in South Africa and other countries to maximize their global aftertax profits and shareholder value. ${ }^{98}$

Finally, South Africa uses the tax system to achieve multiple policy objectives, such as attracting foreign investment (HQC regime), facilitating outbound investment (double tax relief), generating tax revenues (withholding taxes) and protecting the tax base (antiavoidance rules). Each set of rules for achieving the policy objective can be complex on its own, and the various rules have to work together. For example, the Davis Tax Committee recognises that the 'value and importance of a headquarter company regime must not be understated', and that an appropriately designed regime should be 'not only attractive from a tax perspective in terms of tax benefits and ease of compliance', but should also take BEPS concerns into account. ${ }^{99}$

\subsection{Drafting complexity}

Some of the legislative complexity is attributable to how the ITA is organized and the provisions are drafted and arranged. Our analysis is based on comparing the South African ITA and the Canadian Income Tax Act. ${ }^{100}$ We are aware of the fact that tax laws reflect the social contract between the government and the people, as well as the broader social, economic and legal contexts of each country. We are also aware of the shortcomings in comparing the two statutes at a high-level without full consideration of their entire 'ecosystem'. Nevertheless, we believe the comparative approach is helpful, especially when we situate the South African ITA in the broader international tax environment. We provide some examples of drafting complexity below.

$98 \quad$ Transfer pricing is the most important issue addressed by the BEPS Project as it is covered by several action plans. See $\mathrm{n} 10$ above.

99 Davis Tax Committee, The efficiency of South Africa's corporate income tax system: (2018) 88.

100 Canadian ITA, n 46 above. 


\subsubsection{Illogical structure}

The ITA has a poor structure and is organised through arrangement of sections. The sections relating to 'normal tax' do not reveal the inherent structure or logic of the income tax system. In other words, it does not answer such basic questions as: Who is the taxpayer? What is income? How is taxable income computed (for residents and for nonresidents)? How is tax liability determined (typically tax rates and tax credits or rebates)? ${ }^{101}$ Instead, the first few substantive provisions delve into 'levy of normal tax and rates thereof (section 5), tax rebates (section 6) and special credits for medical scheme fees and medical expenses (sections 6A and 6B). The next group of provisions is concerned with specific timing and accounting issues (sections 7-7E) and specific items of income to be included when income is computed, such as gains made by directors of companies (sections 8 and $8 \mathrm{~A}$ ).

In comparison, the Canadian ITA arranges the sections pertinent to international taxation as follows:

101 Canadian ITA, n 46 above, table of content, http://laws-lois.justice.gc.ca/eng/acts/l-3.3/ (visited 18 September 2018). 
- Section 1, short title

\section{Part I, Income Tax}

- Section 2, liability for tax (residents and non-residents)

- Sections 3 - 108, computation of income (including sections 90 - 95 in respect of shareholders of non-resident corporations, such as the CFC rules)

- Sections 109 - 116, computation of taxable income (including sections 115 116 in respect of non-residents)

- Sections 117 - 127, computation of tax

\section{Part XIII and Part XIV}

- Sections 212 - 218, withholding tax and other tax on non-residents

- Section 219, additional tax on on-resident corporations (branch tax)

\section{Part XV, Administration and enforcement}

\section{Part XVI and Part XVI.1}

- Section 245, GAAR

- $\quad$ Section 247, transfer pricing

\section{Part XVII Interpretation}

- Sections $248-262$

\subsubsection{Confusing numbering system}

The numbering system is confusing since Arabic numerals $(1,2,3,4)$ are used for the original sections and subsequent additions are numbered by adding capital letters (4A, 5A, 6A). For further additions, double capital letters (8EA and 8FA) are used. This is then followed by a different numbering system - bis, ter, quat, quin and sex - in some sections, for example sections 6, 11 and 13. This numbering system increases the lack of coherence in the statute. The Roman numeral I, which is used to number sections (for example, sections $9 \mathrm{I}$ and 23I), can easily be confused with the Arabic numeral 1 . It also 
appears that some sections that have been repealed remain in the statute and their headings can be confused with those of the current provision. One example is former Part IA (withholding tax on interest) and the current Part IVB (withholding tax on interest).

The numbering style also complicates verbal reference to a provision, for examples sections 9D(2)(a)(ii)(aa) and 10(1)(bA)(ii)(bb). If a taxpayer (or tax professor) cannot clearly state the section number, he/she might feel that the law is complicated and confusing, even though the confusion is not about actual tax law per se.

\subsubsection{Hidden charging rules}

As mentioned earlier, the sections of the ITA are arranged in a manner that does not provide readers with a clear picture of the structure of the tax system. The key structural elements of a tax system are embedded in definitional sections and are hidden from plain sight. Consider, for example, the question: Is a company liable to pay tax under the ITA? The answer can be found in the definition of gross income in section 1. In the Canadian ITA, this question is answered in Section 2.

Substantive inbound and outbound rules are scattered in different places. The Davis Tax Committee observed: 102

The fragmentation of the provisions increases the risks to business in completing income tax returns accurately as it adds complexity and requires deep professional knowledge and understanding of the law to identify the potential provisions that may find application to the income derived by the business.

\subsubsection{Patchwork}

The need for constant amendment of the legislation to address emerging policy concerns or tax avoidance schemes leads to additions to the ITA. Ideally, the new additions should form part of the organic whole of the ITA. In practice, owing to time constraints and other reasons, they may appear to be just patchwork. The Davis Tax Committee notes the following: ${ }^{103}$

102 Davis Tax Committee Corporate Income Tax Report, n 2 above 63.

103 Canadian ITA, n 46 above. 
The complexity in the Act is manifest in many of the individual provisions on a standalone basis and certainly also in the statute as a whole. The Act has evolved over the last half century (since its last consolidation in 1962) as a patchwork of specific provisions to address specific technicalities and transactional developments - with insufficient regard for overall policy and structure objectives or the desire to retain simplicity.

The Davis Tax Committee identified the specific anti-avoidance rules as the main example: 104

The complexity is often compounded by the fact that these targeted provisions often attack harmless legitimate transactions, where there is no intention to avoid tax. In response, further amendments are drafted to cater for such harmless transactions which results in the unintended consequence of complicating the legislation further.

The Committee considered the anti-diversionary rules in section 9D, the hybrid rules in sections $8 \mathrm{~F}$ and $8 \mathrm{FA}$ and the interest limitation rules in section $23 \mathrm{M}$ to be 'overly broad and excessively complex, which results in often unintentional noncompliance by taxpayers and lack of enforcement by SARS'. ${ }^{105}$ As discussed in Parts 2 and 3 of this chapter, most of these anti-avoidance rules were not home-grown in South Africa, but were transplanted in order to deal with sophisticated international tax planning strategies.

\subsubsection{Inelegant drafting}

The drafting of tax rules is a daunting task! Owing to the tax environment in South Africa and genuine reasons for using complex rules to deal with complex tax problems, the drafting of international tax rules that work for South Africa is likely to be even more daunting. Nevertheless, how the rules are written can add an unnecessary layer of complexity. We provide some examples to illustrate the somewhat inelegant drafting.

Some sections are not self-explanatory. Examples of this are the hidden rules for establishing the basis of tax jurisdiction and the use of cross-references, especially references to schedules that are not in the consolidated ITA (such as the meaning of immovable property for the purpose of section 35A, which can be found in the Eighth Schedule). Definitions are located in different sections, such as subsection 1 or subsection 1 of a specific substantive section, or are cross-referenced to another section (other than section 1).

\footnotetext{
104 Canadian ITA, n 46 above.

105 Davis Tax Committee, n 102 above 89.
} 
Some sections seem to be unnecessarily duplicative. One example is the different regimes for withholding tax on royalties (Part IVA) and interest (Part IVB). Each of these parts has eight parallel sections dealing with:

- sections 49A/50A, Definitions;

- sections 49B/50B, Levy of tax;

- sections $49 \mathrm{C} / 50 \mathrm{C}$, Liability for tax;

- sections 49D/50D, Exemptions;

- sections 49E/50E, Withholding of withholding tax;

- sections 49F/50F, Payment and recovery of tax;

- sections 49G/50G, Refund of tax; and

- sections $49 \mathrm{H} / 50 \mathrm{H}$, Currency of payment to the Commissioner.

Consolidating Parts IVA and IVB would eliminate many unnecessary words without sacrificing the substance of withholding tax rules. The Canadian ITA imposes withholding tax on interest and royalties under section 212(1)(b) (interest) and (d) (royalties).

Some sections are too wordy, especially those dealing with anti-avoidance provisions. For example, the definition of affected transactions in section 31(1) uses more than 200 words to capture cross-border transactions between parties under common control (typically known as non-arm's length transactions):

affected transaction means any transaction, operation, scheme, agreement or understanding where

(a) that transaction, operation, scheme, agreement or understanding has been directly or indirectly entered into or effected between or for the benefit of either or both-

(i) (aa) a person that is a resident; and

(bb) any other person that is not a resident;

(ii) (aa) a person that is not a resident; and (bb) any other person that is not a resident that has a permanent establishment in the Republic to which the transaction, operation, scheme, agreement or understanding relates;

(iii) (aa) a person that is a resident; and

(bb) any other person that is a resident that has a permanent establishment outside the Republic to which the transaction, operation, scheme, agreement or understanding relates; or

(iv) (aa) a person that is not a resident; and (bb) any other person that is a controlled foreign company in relation to any resident, and those persons are connected persons in relation to one another; and 
(b) any term or condition of that transaction, operation, scheme, agreement or understanding is different from any term or condition that would have existed had those persons been independent persons dealing at arm's length;

In comparison, in the transfer pricing rule in section 247 of the Canadian ITA, fewer words are used to capture a broader scope of offensive transactions:

(2) Where a taxpayer or a partnership and a non-resident person with whom the taxpayer or the partnership, or a member of the partnership, does not deal at arm's length (or a partnership of which the non-resident person is a member) are participants in a transaction or a series of transactions and

(a) the terms or conditions made or imposed, in respect of the transaction or series, between any of the participants in the transaction or series differ from those that would have been made between persons dealing at arm's length, or

(b) the transaction or series

(i) would not have been entered into between persons dealing at arm's length, and

(ii) can reasonably be considered not to have been entered into primarily for bona fide purposes other than to obtain a tax benefit,

Furthermore, the phrase 'transaction, operation, scheme, agreement or understanding' is repeated 20 times in section 31. In comparison, section 247(1) of the Canadian ITA defines transaction as including 'an arrangement or event' and uses only the word transaction in the rest of the provision.

The GAAR is arguably not general enough as sections $80 \mathrm{~A}$ to $80 \mathrm{~L}$ provide much specificity, which may undermine the effect of a standard-based rule such as the GAAR. Also, section 80B refers to 'in the context of business' in its definition of an 'impermissible tax avoidance arrangement', while the ITA does not provide any guidance regarding what business entail. The GAAR is divided into twelve sections and contain more than 1800 words, while the Canadian GAAR consists of a single section (section 245) of fewer than 800 words. ${ }^{106}$

106 For the text of section 245, Canadian ITA see http://laws-lois.justice.gc.ca/eng/acts/l-3.3/page264.htm|\#h-157/ (visited on 18 September 2018). 
Those who drafted the specific anti-avoidance rules did not seem to have much confidence in the effect of the GAAR and were not prepared to give it a chance through judicial interpretation. Some SAARs 'are in fact extremely broad and are not sufficiently tailored to the mischief involved', which 'exacerbates the problem of complexity'. ${ }^{107}$ Some SAARs, for example the roundtripping royalty rule in section 23I, may be an overkill for South Africa. Roundtrip financing is covered by the GAAR provisions. Even though roundtripping of intellectual property may be more offensive in terms of South African tax policy, it is conceivable to list it as one type of impermissible tax-avoidance arrangement. Furthermore, the foreign exchange control regulations also limit the offshoring of intellectual property created in South Africa.

\section{Recommendations for simplification}

\subsection{Living with reasonable intrinsic complexity}

\subsubsection{Necessary complexity}

The intrinsic nature of international taxation and the influence of the international tax environment dictate a certain level of complexity. For South Africa's income tax system to address cross-border tax issues associated with having an open economy, a reasonable level of complexity is inevitable. The key is to assess whether the complex tax rules have a simpler alternative, or whether they offer good value for the complexity they create. The main objective of simplification should be to simplify the ITA in a way that does not reduce the effectiveness of the tax system in achieving the multiple policy goals.

We echo the Davis Tax Committee's view on a balanced approach to simplification: ${ }^{108}$

Although tax laws should be drafted simply, this may not always be adequate to address complex situations, as simple rules might undermine ease of administration. Simplicity should not be an end in itself and it should not come at an unacceptable cost in relation to other policy objectives. A balance must be struck. Care should be taken to note that simplicity is not easily taken advantage of by sophisticated taxpayers. 


\subsubsection{Tailored for South Africa}

Intrinsically complex rules created for mature tax systems may need to be tailored for South Africa. Less legislation may be more effective in South Africa's context as legislative "over-kill" tends to create unnecessary complexity in compliance and breed disrespect for the tax system. For example, we are sympathetic to the claim that the CFC rules are too complex, and perhaps unnecessarily so. ${ }^{109}$ Without denying the need for CFC rules to protect South Africa's tax base, these rules can be simplified through, among others, providing safe harbours or more clearly indicating that only foreign non-business income and diverted domestic income of CFCs are subject to these rules.

\subsubsection{Keeping it simple for general taxpayers}

Simplification for ordinary taxpayers can be achieved by clearly indicating the rules that apply to them. For example, the international tax rules have no relevance for companies that are not involved in cross-border transactions. If such rules are clearly indicated or moved to a separate part of the ITA, such companies would not be confused by the complexity of international tax rules. Similarly, many companies do not engage in complex, aggressive tax-planning practices, which are targeted by anti-avoidance rules. Such companies would not consider clearly marked SAARs and the GAAR to be too complex. The wording of each SAAR or the GAAR probably has room for clarification and simplification to ensure that general taxpayers will be in no doubt about the importance of complying with such rules.

Even though SAARs and a GAAR are necessary evils of modern taxation, a holistic review, and perhaps a consolidation of some of these rules, will lead to simplification and enhance effectiveness. In this regard, the various rules on interest deduction may serve as a good example (see table below). ${ }^{110}$

\footnotetext{
109 Tran-Nam, Oguttu \& Mandy, n 90 above; Hoppe, Safaei, Singleton \& Sureth-Sloane, n 90 above. 110 For further discussion of debt financing, see C West \& D West 'South Africa' in 2012 IFA cahiers de droit fiscal international 633.
} 
Table: Selected rules on interest deduction limitations

\begin{tabular}{|c|c|c|}
\hline \multicolumn{3}{|l|}{ Interest expense } \\
\hline Section of the ITA & Issue & $\begin{array}{l}\text { Nature of the } \\
\text { provision }\end{array}$ \\
\hline Section $8 \mathrm{~F}$ & $\begin{array}{l}\text { Denies the deduction of interest incurred or accrued } \\
\text { under a hybrid debt instrument and deems it to be a } \\
\text { dividend for the payer and recipient }\end{array}$ & SAAR \\
\hline Section 8FA & $\begin{array}{l}\text { Denies the deduction of interest incurred or accrued } \\
\text { under a hybrid debt instrument and deems it to be a } \\
\text { dividend in specie for the payer and recipient }\end{array}$ & SAAR \\
\hline Section $8 \mathrm{E}$ & $\begin{array}{l}\text { Deems a hybrid financial instrument as a 'hybrid } \\
\text { equity instrument' in certain circumstances and } \\
\text { dividends on the share are taxed as income (not } \\
\text { interest) in the hands of the shareholder. }\end{array}$ & SAAR \\
\hline Section 8EA & $\begin{array}{l}\text { Applies to equity that resembles debt (preference } \\
\text { shares), where the dividend yields in respect of } \\
\text { shares is secured or guaranteed by third party } \\
\text { balance sheet. It subjects a dividend to tax in certain } \\
\text { instances. }\end{array}$ & SAAR \\
\hline Section 23(q) & $\begin{array}{l}\text { Disallows a deduction of expenditure incurred to earn } \\
\text { foreign dividends related to section } 10 \mathrm{~B}\end{array}$ & SAAR \\
\hline Section 23M & $\begin{array}{l}\text { Limits cross-border interest deductions where a } \\
\text { controlling relationship exists between the } \\
\text { payer/debtor and payee/creditor and the latter is not } \\
\text { subject to tax. It addresses the deduction / no } \\
\text { inclusion outcome if deductible interest is paid to non- } \\
\text { resident and exempt persons. }\end{array}$ & SAAR \\
\hline Section $23 \mathrm{~N}$ & $\begin{array}{l}\text { Limits the use of excessive debt financing to achieve } \\
\text { tax savings in reorganisation and acquisition } \\
\text { transactions }\end{array}$ & SAAR \\
\hline Section 24J & $\begin{array}{l}\text { Deals with the accrual and incurring of interest for the } \\
\text { holder and issuer }\end{array}$ & General rule \\
\hline $\begin{array}{l}\text { Section } 35(2) \text { of the } \\
\text { Tax Administration } \\
\text { Act } 28 \text { of } 2011 \text { (TAA) }\end{array}$ & $\begin{array}{l}\text { reportable arrangement rules that require the } \\
\text { reporting of share buy-backs, hybrid equity and debt } \\
\text { instruments }\end{array}$ & Administrative \\
\hline Sections $80 \mathrm{~A}$ & $\begin{array}{l}\text { Round-tripping may be impermissible tax avoidance, } \\
\text { subject to the GAAR }\end{array}$ & GAAR \\
\hline Section 31 & Intra-group financing & $\begin{array}{l}\text { Transfer pricing } \\
\text { and thin } \\
\text { capitalization }\end{array}$ \\
\hline
\end{tabular}

\subsubsection{Giving the GAAR a chance}

A GAAR is a standard-based rule. Its "ambiguity" can also be its strength as it is impossible for the drafters of ITA provisions to contemplate each and every type of tax avoidance arrangements in the future and craft specific counter measures. The GAAR provisions in the ITA are currently very detailed and complex. South African courts have not had a chance to interpret these provisions. To make the GAAR work effectively, it is 
worth considering using fewer SAARs or simplifying some SAARs so that the GAAR can be invoked to deal with tax avoidance arrangements. Given a chance, the courts may develop sufficient jurisprudence, rendering the GAAR an effective shield for the tax system.

\subsection{Rewriting the ITA}

Without changing existing tax policies and operating rules, it may be possible to rewrite the ITA to make it more user friendly and effective. We acknowledge that this is easier said than done. To begin with, there must be a strong conviction that simplification through rewriting is the right approach. The actual rewriting requires skills and resources and 'would be an extremely difficult process to embark upon'. ${ }^{111}$ Fortunately experiences and lessons learnt in other countries may offer some guidance. In the 1960s, Canada re-wrote the ITA with fundamental policy shifts ${ }^{112}$ and New Zealand went through a rewriting process. ${ }^{113}$

Tax law is complicated. Taxpayers do not enjoy studying the ITA to discover that they have to pay more tax, yet it can be assumed that most taxpayers want to comply with tax law. 'A tax system that people can understand is preferable to one that is complex and opaque.' ${ }^{114}$ We suggest that rationalisation and simplification can be achieved through, among other things,

- having a clear structure that follows the logic of taxation;

- providing a better roadmap by rearranging sections into modules according to the key elements of the tax system;

- using meaningful headings to provide better guideposts for readers; and

\footnotetext{
111 Davis Tax Committee Corporate Income Tax Report (n 2 above) 91. 'Such a process would require an investment of highly skilled and experienced resources over a fairly extended period of time, and would, of necessity, require extensive planning and public consultation.'

112 This reform was influenced by the Report of the Report of the Royal Commission on Taxation (1966) available at http://publications.gc.ca/site/eng/471998/publication.html (visited 18 September 2018).

113 Sawyer, Bornman \& Smith, n 8 above.

114 Davis Tax Committee April 2016 report: executive summary of the final report on macro analysis of the tax system and inclusive growth in South Africa 5.
} 
- using easy-to-say numbering (such as using a unique system for each tier of a section (for example 1 or 2 for sections; 1.1 or 2.1 for new additions; (1) or (2) for subsections; (a) or (b) for paragraphs, (i) or (ii) for subparagraphs, (A) or (B) for clauses; and (I) or (II) for subclauses).

\section{Conclusion}

Drawing on existing literature and our understanding of the international tax provisions of the ITA, we conclude that the tax simplification project in South Africa cannot be divorced from the international tax environment. On the contrary, it must wrestle with the intrinsic complexity of tax rules dictated by the international tax environment. At the same time, South Africa can take advantage of the experiences of other countries in simplifying the ITA. We offer some preliminary simplification ideas in respect of rules that are intrinsically complex and rules that are unnecessarily complex due to drafting. Further research is clearly warranted to ensure that simplification is achieved without sacrificing the effectiveness of the tax rules in defending South Africa's tax base while promoting its tax competitiveness. 